\title{
Trading States, Trading Places: The Role of Patrimonialism in Early Modern Dutch Development
}

\author{
JULIA ADAMS \\ University of Michigan
}

The decline of Iberia in the sixteenth century shook the foundations of world trade and politics, undermining Spain's Asian and American trade monopolies and creating the international opening that spurred other European states and merchants in the contest for overseas markets. ${ }^{1}$ After the waves had subsided in the seventeenth century, the world system had been reconfigured. The United Provinces of the Netherlands had become the first truly global commercial power-the first hegemon. ${ }^{2}$ The rise of the Netherlands to the position of world hegemony is at first glance startling. The seven provinces had a relatively small population (some 1.5 million inhabitants in 1600, compared to 10 million in Spain and Portugal, and 16 to 20 million in neighboring France), and had formed part of the Low Countries, an uneasily aggregated group of seigneuries, cities, and provinces under Spanish rule until the 1570s. Even after the Dutch Revolt against Spain had begun, the Dutch were enmeshed in a bitter war of independence that ended only in 1648. The Netherlands appeared to be an also-ran. Why, then, its surprising success? This question is worth answering, not only because of its intrinsic historical interest but also because it illuminates processes of early modern European development and the mechanisms of politico-economic development more generally.

This essay will argue that the nexus of patrimonial state and merchant elite was a key component of the Dutch trajectory. This factor was a necessary, but not sufficient, cause of the rise of the Netherlands and the genesis of the

A previous version of this essay was presented and discussed at the Netherlands Institute for Advanced Studies in Wassenaar, Holland. I would like to thank the participants in that discussion, as well as Terry Boswell, Femme Gaastra, Marjolein 't Hart, Edgar Kiser, Sharon Witherspoon, and CSSH's anonymous reviewers. The research for this paper was funded by the Social Science Research Council.

1 The causes of the decay of Iberian hegemony are complex and contested and cannot be discussed here. For an overview, see Elliott (1967:177-205).

${ }^{2}$ In this article, the Low Countries refer to what is basically the present-day Netherlands and Belgium; the Netherlands and the Dutch Republic to the seven United Provinces (Holland, Zeeland, Utrecht, Gelderland, Overijssel, Groningen, Friesland, as well as Drenthe, which later became a separate province) and their contiguous dependent territory; and Holland to the largest of the provinces.

$0010-4175 / 94 / 2560-4538 \$ 5.00 \mathbb{C} 1994$ Society for Comparative Study of Society and History 
global political economy which the Dutch helped create. The merchantcontrolled state spun off semi-sovereign corporate bodies, such as the East and West Indies Companies. These bodies were also dominated by merchant capitalists and helped establish the Dutch world trading system. At the zenith of the seventeenth-century Golden Age (Gouden Eeuw), however, the state's spin-off corporations pursued policies that were increasingly at odds with one another. I will argue that this contradiction animated a struggle between the mercantile companies which weakened the western arm of Dutch colonialism. As the luster of the Golden Age dimmed and the hegemonic position was surrendered to England, this weakness played a part in Dutch decline.

My argument revises and builds on previous sociological theories for which the Netherlands has represented both a touchstone and a troublesome anomaly. Most influential and of particular concern here is world-systems theory, which from its inception has recognized the centrality of the Dutch case. ${ }^{3}$ This article argues that world-systems theory identifies important preconditions for the rise of the Dutch and the capitalist world-system but bypasses others, notably the specific role of nascent states and intercorporate dynamics in creating and maintaining the conditions within which merchant capitalism and the Dutch Golden Age flourished. I then proceed to offer an alternative approach, emphasizing the unique configuration of social structures, political and economic, national and international, that first promoted, then undermined, Dutch hegemony. The body of the essay is divided into five sections. The first is theoretical, providing a brief discussion and critique of pertinent world-systems arguments and introducing the concept of patrimonialism as an entree into a configurational way of thinking about the peculiarities of the Dutch. The second and third parts explore the role of the nexus between the patrimonial state and merchant class in the Dutch rise to power, and the fourth deploys historical counterfactual arguments to deal with the subsequent history of intercorporate struggle, which left an indelible mark on the construction of Dutch colonialism. This study closes by reflecting on the implications for our understanding of the decline of the Netherlands and its displacement as hegemon.

\section{WORLD SYSTEMS AND PATRIMONIAL STATES}

The genesis of the capitalist world-system in the sixteenth century was an unprecedented phenomenon. ${ }^{4}$ For the first time, according to Wallerstein, economic specialization and rationalization, rather than imperial force, became the major source of the surplus that reproduced social life. These pro-

3 In addition to Wallerstein $(1974,1980)$, see Boswell et al. (1991), Boswell and Misra (forthcoming), and Misra and Boswell (1993), which have recently addressed the Dutch case from within a world-systems framework. See also Klein's (1982) early, dismissive, critique of world-systems theory offered in the context of a conference on Dutch capitalism.

4 A world-system may be defined as a unit with a single division of labor, by which is meant an economic division of labor, that is "both organized and paralleled by a single set of accumulation processes" (Hopkins 1982:11). 
cesses were associated with "more efficient and expanded productivity," and the profit they generated was realized by exchange on the nascent world market (Wallerstein 1974:38). In the earliest stages, merchants from western Europe carrying capital-intensive mass consumption goods, such as herring, salt, wine and textiles, traded with Baltic countries, which offered grain and timber in exchange. Trade in bulk necessities is thought to have "commercialized everyday life, fostering capitalist relations," 5 while inducing regional specialization: The West developed an industrial base, and the East lapsed into a second serfdom in its predominantly agrarian economy. Thus, the initial core of the world economy came to be located in the Netherlands (and some parts of England and France) by 1600 and the first periphery in Russia, Poland, Prussia, and Scandinavia. ${ }^{6}$

What began as a geographically limited world economy in the sixteenth century encompassed the globe, as core areas engrossed modern agriculture and industry and peripheral areas adopted labor-intensive production and monocultures. The far-flung division of labor was simultaneously reinforced by exploitative relations as ruling elites in core areas began to siphon off surpluses from peripheral territories, even selecting the most profitable form of labor organization in the areas they actively controlled (Wallerstein 1980: ch. 2). Trade was the principal mechanism for shifting this surplus, playing a functionally analogous role to that of the political machinery in a worldempire, which served to force flows of tribute to the center. It would be difficult to overstate the importance of trade in world systems theory; it both conveys and creates economic surplus under capitalism. ${ }^{7}$

The Dutch case is, therefore, an ideal vehicle for a critical dialogue with world-systems theory. The Dutch were, as the eighteenth-century novelist, Daniel Defoe, put it, "the Carryers of the World, the middle persons in Trade, the Factors and Brokers of Europe." 8 Indeed, they built the quintessential

5 See Boswell et al. (1991). The exchange of "luxury" or prestige goods may have been equally important in generating and sustaining the first global trading system, as Jane Schneider (1991) has hypothesized. These goods and the wealth they concentrated were distributed in ways that reinforced core elite hierarchies and were used to manipulate subordinates (such as semiperipheral or middle-level groups) through patronage relationships. The relative role of bulk necessities and prestige goods in the rise of capitalism is still an open question and not only among world-systems theorists. See the debate in the special issue in 1992 of the Dutch journal, Leidschrift, "Het Hollandse Wonder."

6 World-systems analyses follow Fernand Braudel in emphasizing the critical role of the secular rise in bulk trades as the basis of Dutch commercial hegemony. See Braudel (1982:6667).

7 Klein (1982:88-90) is unconvinced that Dutch hegemony derives from mechanisms of surplus appropriation. He argues that the Dutch supplied and linked production factors in novel ways, leading to the positive-sum growth of world trade. Both arguments can be made within the framework of world-systems theory, however; and they do not seem to me to be mutually exclusive.

8 Defoe (1728), quoted in Israel (1989:398). Defoe could afford to be neutral in this instance, as Dutch dominance had already waned. Compare the vitriolic diatribe by seventeenth-century poet, Andrew Marvell, in "The Character of Holland": "This indigested vomit of the Sea" (Marvell 1972:112-16). 
trading state. Small wonder that the Dutch case occupies an important place in Wallerstein's texts and later work in world-systems. Explicating the workings of the Dutch system must surely be the acid test of a theory purporting to explain the levers of exchange and expansion underlying the emergent world economy.

In spite of their focus on the total system, world-systems theorists can and do ask why a specific region or country assumes a hegemonic position within the overall structure. ${ }^{9}$ In the early modern period, the most successful should have been those that managed to specialize in the skills needed to command the central place in the emerging world-economy. They were best, that is, at exploiting discrepancies between production costs and the price of goods, and most effective at maintaining their control over differentials in cost and price, whether by depressing expenses (often by coercing labor), raising prices (e.g., monopolizing markets), lowering transaction costs (e.g., cutting costs of transport), or some combination of these strategies. They also relied on the "non-market assist of state machineries" to support the economic goals of their dominant capitalist classes. Their "strong states" enforced and fought over the terms of trade under which exchange took place, without intervening directly in economic production and extraction themselves (Wallerstein 1974:38, 200).

Taking the above premises as givens for the moment, a world-systems theorist's answer to why the Dutch were best equipped to take advantage of the fall of the Iberian empire would stress three basic factors. First, northwest Europe had significant geographic advantages. The Netherlands in particular were located at the intersection of European trade routes, accessible by sea, three major rivers, and an extensive canal network. These features helped the Dutch take advantage of the new commercial opportunities (Wallerstein 1974:266, 272). Second, technical and organizational innovations lowered the production and transaction costs of trading for merchants operating in the Netherlands' sphere of influence. Innovations in shipping and shipbuilding were particularly important in cutting costs of transport and exchange (Wallerstein $212-13,265$ ). Finally, the state's relative strength was a factor in enforcing the advantage, although the way in which that factor came into play is disputed. Holland was simply stronger than other contending states at this juncture, according to Boswell et al. (1991). Wallerstein disagrees, arguing that "Holland was no political threat, unlike France and England." He

${ }^{9}$ Important social features and dynamics are supposed to take place on the level of the whole system rather than emanating from relatively autonomous societies or states. "The premise is that the arena within which social action takes place and social change occurs is not 'society' in the abstract, but a definite 'world', a spatio-temporal whole, whose spatial scope is coextensive with the elementary division of labor among its constituent regions or parts and whose temporal scope extends for as long as the elementary division of labor continually reproduces the 'world' as a social whole (whether on an expanding, contracting, or unchanging scale)" (Hopkins et al. 1982:42). 
stresses, instead, the dearth of other candidates for the position that were weak enough to be acceptable to Spain (the fading, but still powerful world empire). Thus, he claims, the early modern Dutch state could obtain the best terms of exchange for merchants in a relatively peaceful, even apolitical fashion. "Her route to riches was not that of the incipient mercantilism of other states-essential for long-run advantage but not for maximizing shortrun profit by the mercantile and financial classes. Her route was the route of free trade" (Wallerstein 1974:213). I will take strong issue with this point below. 10

There is much to be valued in world-systems theory and in its specific arguments with respect to the Netherlands. First, it seems clear that processes of economic specialization and rationalization were key in a number of sectors that linked up with and supported expanding global trade. In agriculture, these processes were underway by mid-century, especially in Holland; and agrarian autarky was eroding. Data was scarce and unreliable, but several factors indicate that there was a rise in production for supraregional markets: first, the rise in Baltic grain imports and the shift of farmers away from bread grains to dairy farming and horticultural crops like flax, hops and hemp; second, the growth of population without an increase in rural underemployment; and third, an influx of labor and capital into interregional and international trade in bulk commodities (Jan de Vries 1974:71-3, 165-73; Van Houtte 1964).

This feat was possible, it must be pointed out, because the characteristic economic mode of production in the northern provinces in the sixteenth century was petty commodity production, which raised fewer barriers than a legacy of feudalism to agrarian development. ${ }^{11}$ Agrarian feudalism had never predominated to the extent that it had in the southern provinces, in France, or in England, and had not been implanted at all in the coastal and northern provinces. ${ }^{12}$ It is also true that the development of capitalist production relations eventually restructured relatively homogeneous groups of petty commodity producers, making Dutch agriculture the most technically advanced and high-

10 In his later work, Wallerstein moves closer to arguing for the relative strength, rather than weakness, of the Dutch state. See Wallerstein (1980: ch. 2). Note that the above paragraph is a more generous reading of Wallerstein than one which simply lists all the factors mentioned in his texts, as these factors do not always follow from the theoretical premises. For example, he lists as additional causes of the rise of the Dutch "cumulating economic advantage" (1974:212), which is an ad hoc addition, and the "relative financial soundness of state" (1974:213), a variable which is inexplicable within the terms of the theory.

11 This argument derives from an important strand of Marxism, which emphasizes the degree to which the character of production relations structures the role and economic impact of merchant capital. For the kernel of this argument, see Marx (1967, vol. 3: 325-31). Brenner (1977, 1985) developed it further with respect to the genesis of capitalism in western Europe and criticized world-systems theory on that basis. The argument in this essay may be seen as complementary to Brenner's critique.

12 See Jongkees (1942:206-14) and Vlekke (1945:106-11). In the poorer and more thinly populated eastern agricultural provinces, notably Overijssel, feudalism had been more pervasive; and the rural nobility had more power (Slicher van Bath 1957, Vol. 1). 
ly productive in Europe by the eighteenth century. ${ }^{13}$ No doubt this restructuring helped the Netherlands sustain the hegemonic moment. At this early stage, however, agrarian development was probably driven by rationalization and intensification of cultivation, as world-systems theory would suggest, rather than a fundamental shift in class relations away from petty commodity production. ${ }^{14}$

Furthermore, geography and technical and organizational innovations enabled the commercial and manufacturing sectors to absorb and deploy the increased inputs of labor and capital freed up by the agrarian sector. As Wallerstein notes, the merchants of the Low Countries were among those merchants geographically positioned so as to be able to yoke together the northern European markets, where grain and salted fish, furs, woolens, wood and iron were exchanged. Antwerp was northern Europe's entrepôt for textiles and Asian products in the mid-sixteenth century (Ramsay 1986), while Amsterdam served as the staple for the world grain trade, the so-called mother trade (moedernegotie), underpinned by the rising agricultural exports (Den Haan 1977:27-31; North and Thomas 1973; Van der Wee 1988:25-33). As early as 1540 , Hollanders claimed a seagoing fleet of 400 ships, "greater in numbers (they said) than all the merchantmen of England, France, and Brittany combined" (Tracy 1985:195). Improvements, such as the efficient flute ship (fluytschip) and the rederij system, in which commercial and shipping ventures were divided into small shares, dispersed risk and lowered interest rates, enabling Dutch merchants to cast a wide net for capital. ${ }^{15}$ These processes particularly stimulated economic growth in Holland and Zeeland (Van Dillen 1970:239-48; Boxer 1965:6-7).

But the conjoint presence of these factors was not enough to guarantee commercial and financial ascendancy nor predominance in manufacturingand still less the combination of all three that confers hegemonic status. ${ }^{16}$

13 In a region of Friesland studied by Jan de Vries, the peasantry gave way by the eighteenth century to the familiar agrarian capitalist triad of landlords, capitalist tenant farmers, and wage laborers. A similar tendency prevailed in Holland, except that landlord and farmer were more likely to be the same person. The size of farms increased, and the number of farmers shrunk with respect to the area population, while the number of non-landholders grew (De Vries 1974:12736). See Mokyr (1975:296) regarding Dutch agricultural productivity in the early nineteenth century.

14 Van der Wee's (1978) work supplies what seems to me to be strong evidence for this point. His research has shown that the number of small farms actually increased in Holland during the sixteenth century, while their average size decreased. At the same time, however, money rents and yield ratios rose.

15 On these technical and organizational breakthroughs, see Jan de Vries (1976:118). Barbour (1950) notes that the paucity and expense of land in the Netherlands encouraged investors of all economic strata to put their savings into shares in ships, fishing, and land reclamation (and later, as we shall see, in the state debt).

${ }^{16}$ Hopkins et al. give a working definition of hegemony as that circumstance when "no second power or combination of second powers seems capable of challenging effectively the economic supremacy of the strongest core power" (1982:52). Wallerstein (1974) suggests that economic supremacy consists in predominance over world agro-industrial production, trade, and finance; 
Until the Revolt and the remaking of the state, large-scale Dutch merchants functioned primarily as commercial and financial agents of merchants based in other regions. Jonathan Israel has noted that access to the Baltic "rich trades" of spices, sugar and textiles was controlled by the merchants of Antwerp, Hamburg and Lubeck until the 1590s and that grain trade to Italy was organized and financed by the established mercantile elites of Venice, Genoa, and Tuscany (Israel 1989; see also Van der Wee 1965-66:267-85). In the textile industry based in the town of Leiden, the large drapers were captive factors of the merchants of Calais and the Hanseatic League until after the Revolt (Howell 1986:67-69). Their dependent status acted as a brake on merchant intervention in production and on the transformation of petty commodity production carried out in master artisanal households (the dominant form until the 1590s) into capitalist manufactories. ${ }^{17}$ Dependence extended to the Indies trades: Dutch merchants procured both Asian pepper and spices and Caribbean salt from the Portuguese (Bruijn et al. 1979; Van Dillen 1970:139 43; Goslinga 1971:116-25). Although the groundwork had been laid for the linkage of the development of agrarian capitalism, world trade, urban manufacturing, and finance that took place in the 1590s after the ouster of the Spanish, Dutch merchants had not yet transformed themselves from passive channels of exchange into active initiators of trade and investment.

The missing ingredient in the mechanism of transformation was the state, a crucial factor in the rise of the Dutch. To its credit, world-systems theory has tried to highlight the role of politics in the rise of capitalism, deeming the presence of a "strong" state integral to surplus extraction and capital accumulation. ${ }^{18}$ At times, the strength of a state is equated with certain structural features, principally bureaucratization, military rationalization, and public finance; but this equation runs afoul of the fact that the Dutch state lacked these features, remaining what Wallerstein himself calls a "jerry-rigged" apparatus until the end of the early modern era (1980:38). ${ }^{19}$ More often, and more consistently with respect to the theory, states are functionally defined and

while Boswell and Misra (forthcoming) opt for the domination of leading economic sectors, which in this period was trade. By either definition, the Netherlands was the hegemonic power for a large part of the seventeenth century.

17 Sixty percent of the members of Leiden's town council were involved in the key textile industry. Yet until the Revolt the council bowed to external constraint, restricting the numbers of cloths drapers could produce as well as the level of their participation in international trade. See Howell $(1986: 55,69)$ and Posthumus (1908, vol. 1: 275).

18 "Once we get a difference in the strength of the state machineries, we get the operation of "unequal exchange" which is enforced by strong states on weak ones, by core states on peripheral areas. Thus capitalism involves not only appropriation of surplus-value by an owner from a laborer, but an appropriation of surplus of the whole world-economy by core areas" (Wallerstein 1974:401). This is a promising idea, although the mechanisms of surplus transfer have not been spelled out.

19 In her critical review of Wallerstein, Skocpol (1977) notes that this equation also forecloses analysis of why states with so-called strong features did in fact appear in the semi-periphery (for example, Swedish absolutism). 
defined in terms of their specific function in maintaining the structure of the world economy. By definition, a strong core state is expected to secure market advantage and enforce the best terms of exchange for capitalists at the expense of other strong states and weak states in the periphery or semi-periphery.

There are some serious problems with this line of reasoning, however. Most fundamentally, the assumption that the existence and form of a state is mandated by its function in a larger system, in this case the world economy, goes beyond functional description to reduction. Certainly the function of a given social structure may play a role in that structure's creation and reproduction. But to be credible, the argument should also show either that social agents believed that the structure promised to fulfill such a function and their belief played a role in its genesis or maintenance or else that the creation of such a structure was an unintended consequence of some other line of action. ${ }^{20}$ Given the basic assumptions of world-systems theory outlined above, no such mechanisms can be specified. On the contrary, the world-systems approach assumes that the ultimate success of a state's hegemonic project indicates both that the core state in question was necessarily a "strong" one and that its policies emanated from an omniscient globally oriented capitalist elite. These tautological assumptions make it impossible to examine either the variable relationships between states and classes (and fractions of classes) or the ways in which state power is systematically structured by institutional forms and patterned struggles within and among states.

There are good theoretical and historical reasons for thinking that these elements do matter and that the concept of the strong state is an inadequate tool for analyzing early modern European states. These were patrimonial states in the making, not fully constituted sovereign entities, as the concept of a strong state implies. These nascent systems of rule were marked by a segmentation or parcelization of sovereign power among the ruler (or rulers) and corporate elites. The patrimonial ruler ruled, gather funds and deploying power, by relying on self-governing corporations charged with key economic and political obligations, such as estates, guilds, chartered companies, and so on, which were charged with the tasks of formulating and enforcing collectively binding decisions on the people and activities under their jurisdiction. Corporate elites derived economic resources, representation, and symbolic legitimacy in return. ${ }^{21}$

The interdependence between state and corporations was a basic feature of the system of rule, whether the patrimonial ruler dominated the state, as in the absolutist tendency, or the elite-headed corporations did, as in the estatist

20 Stinchcombe (1968:80-101) discusses the logical conditions under which functional reasoning is valid.

21 For the concept of patrimonialism, see Max Weber (1968:226, 293-97, 1006-7, 1010-13, $1022,1028-31$ ). 
mode prevalent in the Netherlands. ${ }^{22}$ Yet, similarly, there were also permanent tensions between rulers and corporate bodies (since the latter typically aimed at both power and profit, at maintaining their sovereign rights as well as expanding their economic resources), and among the corporations themselves, which were often assigned incompatible mandates and overlapping jurisdictions. Those tensions continued to be developmentally significant until that time when states became superordinate powerholders and the political functions of the patrimonial corporations were subordinated or eliminated.

In the Netherlands, I will argue, the relationship between patrimonial state and merchant class was unique among early modern European contenders for power, and estatist patrimonial structures of rule are a central part of the story of the Golden Age. The next two sections of this essay show how patrimonialism reinforced the politico-economic privileges and powers of key segments of the urban merchant elite, first under the Habsburg crown, and then under the newly independent Dutch state itself.

THE STATE-MERCHANT NEXUS: REVOLUTION AND STATE POWER IN THE NETHERLANDS

While still the patrimonial overlord of the Low Countries, the Habsburg Crown had strengthened the position of the urban regent patriciate in several ways as a counterweight to the nobility, which began to withdraw to rural estates even before the Revolt (Van Nierop 1984). The Habsburg rulers not only supported the efforts of towns to buy up the remaining seigneuries around their walls and expand their control over the economic activities of their hinterlands ${ }^{23}$ but also consulted towns and provincial States with respect to taxation and new laws and (customarily) decisions on war and peace which affected the provinces (Koenigsberger 1982:103-4). Crown military projects and fiscal demands then molded pre-existing inter-urban networks into more organized and potentially solidary provincial estates (Blockmans 1978), in which wealthy merchants occupied an usually powerful place, controlling the crucial town councils by mid-sixteenth century. In Holland and Zeeland, most of the councilors were either shipowners or directly involved in overseas trade (Boxer 1965:7-8; Burke 1960:30; Kossmann 1978:5-8).

The crucial stage of the Revolt began in 1572, when the relationship between the Crown and the Low Countries estates buckled under the combined pressures of financing Spain's war with France, the administrative efforts to

22 Regarding estatism, see Weber's comments on "rule by notables (honoriatores)" (1968: 1009-10,1038-42). The term estatism is preferable, in my view, because it makes explicit the conceptual and historical parallel to absolutism.

23. See Jan de Vries (1974:48). The Netherlands were highly urbanized, with many sizeable towns, rather than one or a few large ones. Fifty-two percent of Holland's population already lived in towns in 1514 (Baelde 1988:69), and this percentage rose further during the sixteenth century (Jan de Vries 1984). 
bring the restive territories more firmly under Spanish control, and the Inquisition's effort to extirpate Protestant heresies and reimpose Catholic orthodoxy. Emperor Philip II was not successful in asserting politico-economic authority over the Dutch regents; the absolutist move failed. Instead, the regents captured the state, and the estatist tendency triumphed. The Dutch States-General gained effective sovereignty in part of the north by the mid-1570s, and the delegates of several of the provincial States formed a defensive pact against Spain, known as the Union of Utrecht, in 1579. The pact ultimately served as the basis of the new state, although the territory it covered waxed and waned with the fortunes of the Eighty Years War. ${ }^{24}$

As many historians have pointed out, the turning point for the Dutch Revolt hinged on a specific politico-economic intervention which had positive consequences for Dutch mercantile accumulation and consolidation of political power. In 1585, the Dutch succeeded in blockading the Scheldt river after the Spanish recaptured Antwerp, permanently preventing trading ships from reaching that city. The closing of the Scheldt ended Antwerp's role as the key textile and Asian product entrepôt, but Antwerp's loss was Amsterdam's gain. Some 60,000 to 120,000 refugees from the southern Netherlands, fleeing economic hardship and religious persecution, brought their substantial capital and industrial and commercial skills to the north (Briels 1985:213-28; Gaastra 1982:11). Amsterdam merchants were able to gain increasing leverage over the flourishing trade in raw wool (Van Houtte 1964). Textile manufacture in Holland towns boomed; in Leiden, it registered a rise from 38,130 pieces in 1588 to 73,047 in 1609 (Posthumus 1908-39, vol 2:60-4, 107, 129).

In retaliation, Philip II (also king of Portugal from 1580 to 1640 ) embargoed all foreign ships in Iberian harbors in 1585, an action aimed primarily at the Dutch (Bruijn et al. 1987:1-6; Boxer 1965:42). Philip followed this up in 1594 with a ban on Dutch trade in the Americas (Van den Boogaart 1982:1156). The barriers to using Iberia as the accustomed mercantile intermediary, coupled with the infusion of capital and skills from southern émigrés and newly available knowledge about trade routes and territories, provided the means and impetus for Dutch merchants to initiate their own voyages to Asia in the $1590 \mathrm{~s}$, and after that precompanies (voorcompagnieen) multiplied rapidly in Holland and Zeeland (Gaastra 1982:11). By 1601, fourteen fleets (sixty-five ships) had sailed to the East Indies, far more than even the Portuguese had sent in that period. Similar efforts at expansion took place in the Atlantic. Dutch merchants traded actively in Brazil despite Philip's ban and smuggled salt out of the Caribbean in spite of the declared Spanish monopoly. From 1593, Holland and Zeeland merchants formed precompanies to compete with Portuguese slave traders on the Guinea coast (Van den Boogaart 1982:115-6; Van Dillen 1970:139-43; Goslinga 1971:116-25).

24 Parker (1977) provides a concise English-language history of the upheaval. 
Traditional patterns of exchange based on bulk transport now broadened to incorporate other high-value commercial streams in addition to East and West Indies trade. As Jonathan Israel shows, the Dutch advanced dramatically in Baltic, Russian, Mediterranean, and Caribbean markets (Israel 1989:43-66). Domination of these trades required more than entrepôt storage space; it also depended on the growing textile industry mentioned above. The leading edge of commercial expansion shifted to the colonial and rich trades, and the merchants engaged in colonial trade, proclaiming the need for the state to help merchants secure wider opportunities in the Indies, swept into power in Amsterdam in 1601 (Elias 1923:44-6). Heading the group were the precompany directors, Reynier Pauw and Gerrit Bicker, soon to be founding directors of the East Indies Company.

Thus, the position of merchants within the governing coalition, particularly the long-distance merchants of the colonial and rich trades, was greatly strengthened. Politico-economic development before the Revolt and then the course of the Revolt itself propelled Holland and Zeeland merchants to the forefront of the Dutch elite and consolidated a revolutionary coalition which bound to the merchants disaffected nobles, pirates, manufacturers, burghers, and anti-Spanish Calvinist preachers. It was this motley group-dubbed "Hogglanders", "Butterboxes", and "Sovereign Lords Millers and Cheeseheads" by their envious English rivals-that struggled to carve out the outlines of a new state.

The state-builders pursued two strategies in these formative and combative years. In the earliest phase, punctuated by military threats to the integrity of the United Provinces themselves, the States-General appointed foreign quasimonarchical protectors chosen on the basis of Dutch alliances with France and England, respectively. This first strategy, weak patrimonial absolutism, involved drafting a foreign substitute for the now defunct Habsburg monarch. The second phase, favoring a rational-legal bureaucracy, saw a pioneering effort to build an integrated central state, based on an attempt to eliminate venal officeholding and to transform the Council of State (Raad van State) into the nucleus of a national administration. ${ }^{25}$ Both strategies foundered on the rocks of urban and provincial opposition and the merchant class's organized resistance articulated via patrimonial state bodies. In particular, the mercantile elites of the States of Holland refused to relinquish control over maritime policy or the naval dominance they had established in Low Countries waters. ${ }^{26}$ The regents consistently resisted any perceived erosion of their

25 The regents in the Holland States banned venality of office in 1579. No general law against office sales was enacted during the Dutch ancien regime, due to provincial sovereignty. See Swart (1949:68-78). Elsewhere I discuss in detail these state-building strategies and the limits placed upon them by patrimonial structures. See Adams (1990).

26 They went so far as to suborn the Council of State in order to block government investigations of illegal collaboration in smuggling and customs fraud subsisting between the Amsterdam admiralty and leading merchants (Vlekke 1945:147, 153; Elias 1963: xl-xli). Their objections 
particularistic powers and privileges. They ousted the foreign protectors, and their organ, the States-General, pruned the powers of the Council in 1588, restricting it to implementing the State's directives. The States-General declared itself in 1590 "the sovereign institution of the country," with "no overlord except the deputies of the provincial estates themselves." 27 The founding Union of Utrecht, which did not establish common central institutions, became the basis of the estatist patrimonial state and the closest approximation to a constitution.

As R. R. Palmer remarked, the intricacies of the independent Dutch state "baffle brief description" (1959, vol. 1:38). We need only review the most important features here. The Union reserved sovereignty to the provincial assemblies and empowered the States-General to enact only what had been previously agreed upon in those bodies. The provincial States were to agree unanimously in the big decisions on war, peace, and taxes affecting the whole Union. And the provincial States were in turn largely delegates of the fiftyeight voting (stemhebbende) towns. ${ }^{28}$ Thus, about 1,500 regents-town councilors and magistrates, together with the members of the upper judicial and governmental colleges and high administrative officials-were reaffirmed as the ruling elite (Fockema Andreae 1969:36-9; Schoffer 1988).

Not that the state worked perfectly, even from the start. At times of national crisis, when its centrifugal tendencies were most apparent, the regents fell back on the indigenous Stadholders appointed by each province (traditionally but not necessarily, the Princes of Orange), whose powers they had sharply circumscribed but not eliminated. Some of the stadholders sought to lay claim to the monarchical prerogatives vacated by the Habsburgs but still close to the hearts of many of the populace. The Princes of Orange had traditional prestige, dynastic connections, military duties as the head of the army, and a say over the composition of some provincial assemblies via power over certain town government elections. Even when the regents governed alone during the stadholderless eras (self-servingly dubbed the Eras of True Freedom, or Ware Vrijheid), their politico-economic position and legitimacy was linked to the stadholderate as one of the few symbols of national unity. Yet the Stadholders were not successful in claiming sovereign status during the sixteenth and seventeenth centuries. As Simon Schama puts it, "In wartime, the Stadholder

were focused further by the presence of a formal representative of England on the Council, raising doubts and complaints about its independent sovereign status.

27 Although struggles between the States and the Council continued into the early seventeenth century, the Council lacked institutional capacities to conduct a national policy or to enforce sovereign directives on recalcitrant provinces, towns, or corporations (Fockema Andreae 1969; Elias 1923:30).

${ }^{28}$ In Holland the towns held eighteen out of nineteen votes. In Zeeland only one noble, the Prince of Orange, voted. In the northeast, States membership derived from the ownership of areas in which franchise-holding farms had stood, but the city oligarchy controlled participation. In Overijssel, the three towns had three votes to the nobility's one. In Groningen, the city and nobility had one vote each. In Friesland the towns had only one vote out of four. For an Englishlanguage resume of the mechanics of urban voting prerogatives, see Vlekke (1945:162-64). 
existed in an uneasy capacity, part warlord, part commissioned officer; in peacetime his role was even more presidential-patriarchal, rather than royalgovernmental" (1987:67). ${ }^{29}$

The power of the Holland and Amsterdam regents over the other provinces and the stadholderate, consistently evident, was exercised through multiple mechanisms. First, the merchant-regents established ideological hegemony. "It is true that the State is seen as the organ of one particular group, destined to create favorable conditions for the latter's maximum expansion," writes Gramsci. "But the development and expansion of the particular group are conceived of, and presented, as being the motor force of a universal expansion, of a development of all the "national' energies" (Gramsci 1971:182). In just this sense, the merchant-regents successfully campaigned for support from or acquiescence by other provinces and groups on the basis of the positive impact of their politico-economic projects on the Netherlands as a whole (see Schoffer 1964:64-98). ${ }^{30}$

Second, in the key policy areas of international commercial and colonial politics, the power of the Amsterdam and Holland regents was rapidly configured into political structures themselves; and ideological power was married to institutional clout. The Holland States and Amsterdam town council appointed and provided the key personnel in matters of foreign policy, tax collection, and the navy. The Grand Pensionary of Holland usurped the place of the States-General's Griffier and served as a kind of Prime Minister, formulating and conducting foreign policy initiatives. Holland appointed and paid almost all diplomats; Amsterdam itself controlled (appointed and paid) many ambassadors, including those for Paris, the Scandinavian countries, and the Hanseatic cities. These diplomats sought guidance from their provincial and town authorities as well as the States-General (Boogman 1979:396-7). Eventually Holland also appointed and dominated three of the five naval admiralties charged with collecting the Convoy and License monies (taxes on shipping) that maintained the navy, a fact which would turn out to be crucial in sealing the province's, and Amsterdam's, dominant position.

Finally, if other cities, provinces, or the Stadholder resisted more tactful leadership, the Holland regents had (and used) what amounted to a fiscal veto over policy implementation. Holland contributed at least 59 percent (and often up to 66 percent, if not more) of the state's annual budget, and Amsterdam a significant portion of Holland's. ${ }^{31}$ Of this, the regent elite paid a substantial share. In 1600, about half of the Amsterdam regents were large-

29 Two good English-language accounts of the relationship between the regents and stadholders are Rowen (1988) and Vlekke (1945). Note that the provincial States were not legally bound to appoint the same individual to each provincial stadholderate until 1747.

${ }^{30}$ It seems to me symptomatic that the illustrious Dutch jurist, Grotius, authored both the international maritime doctrine of "Mare Liberum" and a domestic political theory that enabled the collective rule of the regents and provincial estates over their would-be sovereign monarchs.

${ }^{31}$ Estimates of Amsterdam's share differ fairly widely, however, from about 15 to 50 percent. For a recent discussion of this issue, see Marjolein 't Hart (1989). 
scale merchants (Burke 1974:43, 58). The merchant-regents' fiscal resources helped keep the unwieldy ship of state afloat, and they laid heavy hands on the tiller. ${ }^{32}$ These mechanisms-institutional, ideological, and fiscal-awarded merchant capitalists, especially those of Amsterdam, extraordinary say in formulating commercial, colonial, and indeed general, state policy goals.

PATRIMONIALISM, CHARTERED COMPANIES, AND THE RISE OF THE COLONIAL INTEREST

The fledgling state, committed to promoting international commercial interests, faced its first significant challenge when the growing competition among precompanies provoked higher spice prices in Asia and lower selling prices in the Netherlands, endangering the profits of the precompanies themselves. The alliance between the Amsterdam regents and the Holland Grand Pensionary, Johan van Oldenbarnevelt, who encouraged and mediated negotiations among those concerned, persuaded other merchants to put aside their fears of Amsterdam's dominance and to pool their efforts; and the state chartered the East Indies Company (Verenigde Oost-Indische Compagnie, or VOC) in 1602.33 The charter awarded the VOC a twenty-one-year monopoly on trade east of the Cape of Good Hope. The tripartite monopoly covered shipping, objects of trade, and their sale in the Netherlands. The charter also delegated sovereign rights to the company, while rendering it dependent on the state for the recognition and renewal of its monopoly privileges and territorial claims and for the domestic support of its monopoly. The East Indies Company was a patrimonial state creation and a merged partnership of state and merchant class from the start.

The VOC was both innovative and traditional. One of the first examples of a limited liability company, it pioneered the concept of permanent capital and a partial distinction between company and individual assets. ${ }^{34}$ As such, the VOC was able to attract a strikingly broad range of investors and to accumulate an unprecedented initial capital, which reached the then huge sum of $6,424,588$ guilders (florin). However, the company was representative of the Dutch economic elite, both in class and regional terms. Most initial share-

32 Hence the structure and composition of the Amsterdam government was crucial. The thirtysix members of the town council (vroedschap), propertied men chosen for life by cooptation, not only supplied a list of regents from which the four mayors were elected annually but also participated in the election of the aldermen (schepenen) responsible for making laws. The council also advised the mayors, who headed the council, supervised religious and poor relief institutions, oversaw taxation and the city's financial institutions, the civil militia and army garrisons, and appointed representatives to the Council of State and the Admiralties. See Porta (1973:23-5).

${ }^{33}$ The foregoing is drawn from Gaastra (1982:9-11) and Prakash (1987:185-6). A reproduction of the charter can be found in Cau (1658, Vol. 1:530ff).

34 The major improvements over the precompanies were that shareholders contributed to the company itself, not to individual directors; that they contributed for a period of ten years, not one voyage; and that directors were not personally responsible for company debts, while shareholders were responsible only for up to the amount of their investment. See Van Dillen (1958:20-34). 
holders were large-scale wholesale merchants who also invested proportionately the most money (Van Dillen 1958:45-49). Amsterdam investors supplied 57 percent of the initial capital. ${ }^{35}$ As they continued to buy up smaller shareholders, the number of shareholders in the Amsterdam chamber shrank from 1,143 in 1602 to 830 in 1612 (Van Dillen 1958:45-49). The first directors were also merchants. Thirty-six men served as directors of the Amsterdam chamber in the 1602-17 period. Of those on whom I have data, twenty-four were large-scale wholesale merchants, and one was an admiral (Adams 1990: Appen. I)

The corporation was also created in the image of the estatist state. The charter distributed policy-making and operations across six chambers ( $\mathrm{ka}$ $m e r s$ ) and a regionally balanced court of directors. Each chamber was to build and furnish its own ships and recruit its own sailors, while return cargos and profits were to be proportionally redistributed. Eight of the central court of seventeen directors, the Gentlemen XVII (Heren XVII), came from Amsterdam, four from Middelburg, one each from the four small chambers, and a seventeenth was to be elected either from Middelburg or one of the small chambers. ${ }^{36}$ Vacancies among the directors were to be filled by cooption from short lists of large shareholders given by the chamber directors in question to the magistrate of the relevant town, a mechanism that promised even closer ties between company and urban elites (Gaastra 1982:17-21). These ties were close from the beginning: Of the thirty-six initial directors of the Amsterdam chamber, at least ten can definitely be said to have held city office; and a number of them were opinion leaders and key political players in the town council.

Profits and power were the watchwords of the company, as they were for all patrimonial corporations. Grand Pensionary van Oldenbarnevelt asserted in 1602 that a company was necessary "for damaging the enemy and for security of the fatherland." ${ }^{37}$ The VOC was successful from the outset. Mounting an offensive against the Iberian empire in the East Indies, with a view to making money and cutting the costs of war to the States-General, the VOC made rapid inroads in the spice islands, the South Moluccas and Banda Islands, the source of the world's cloves and nutmeg, forcing the Portuguese off Amboina in the Moluccas in 1605 and securing a foothold in Ternate and Tidore. Some merchant investors resisted this bellicose turn of events (Van Dillen 1958:19). In 1608, and again in 1613, some protested and withdrew from the company; but they had no discernable impact on policy. The Dutch route to mercantile

36 The initial investments of the chambers were: Amsterdam, 3,679,915 guilders; Middelburg (Zeeland), 1,300,405; Delft, 469,400; Rotterdam, 173,000; Hoorn, 266,868; Enkhuizen, 540,000 (Gaastra 1982:22).

${ }^{37}$ Quoted in Boxer (1979:1). The founding of the VOC was an extension of the policy by which the States of Holland and many towns gave the precompanies arms and exempted them from duties. Unlike the VOC, however, the precompanies neither had sovereign rights nor made claims to sovereignty. 
riches was not the route of free trade, pace Wallerstein. Rather, it was an explicitly coercive politico-economic project. The VOC's commercial and military success transformed the international balance of power and helped to hurry Spain to the negotiating table, where Dutch colonial projects had suddenly become bargaining chips.

At this stage, the accumulation strategies of Dutch carrying traders and colonial merchants were contradictory; and they voiced opposing interests in the outcome of the negotiations with Spain. The carrying traders wanted peace and were willing to trade away the possibility of colonial gains to get it. The colonial merchants strongly opposed the Grand Pensionary's proposal that the VOC be liquidated and plans for a West Indies Company scrapped in exchange for Spanish recognition of Dutch independence. The most vociferous opposition emanated from the Amsterdam town council, which argued that peace would damage trade and privateering in the Indies and that the West Indies Company, backed by the council since 1606, would never be realized (Elias 1963, Vol. 1:xlix; Hoboken 1960:48). Despite their opposition and that of the Stadholder and the hard-line Calvinist clergy, the Twelve Year Truce was signed in 1609. The majority of the representatives to the Holland States had come to support the Grand Pensionary and an end to the hostilities. The States of the land provinces had also supported peace, hoping for lower taxes. The Truce specified that Spain recognized the independence of the United Provinces and that both would keep their Indies possessions. ${ }^{38}$

The Truce did benefit European carrying traders, shipbuilders, and sailors $^{39}$; but it could not produce a permanent peace because of domestic opposition. The VOC's success continued to strengthen the hand of the colonial traders and the Amsterdam City Council, and their opposition ultimately carried the day. The Heren XVII propagandized against the Truce at home, actively petitioning the States-General, provincial States, and key town councils, while "their men in the Indies" worked to seize as much territory as possible and to monopolize the world spice trade (Furber 1976:34; Israel 1982:13-5, 36). During the Truce, the VOC defiantly expanded its operations in Asia, sending to Asia 76 ships carrying 8,500 men from 1602 to 1610 and 117 ships and 19,000 men from 1611 to 1620.40 The company designated

38 Parker neatly sums up the situation from Spain's point of view: "Spain was not prepared to abandon for ever her monopoly status in the New World, but neither was she prepared to continue fighting in the Netherlands for the sake of the Portuguese Indies" (1979:54-55).

39 Danish Sound toll data show that the Dutch position in the Baltic improved tremendously: The Dutch share of total ships entering the Baltic rose from 60 to over 70 percent in 1609-20, a level never reached again (Den Haan 1977:141, 197-9; see also Christensen 1941). The Dutch part of the Mediterranean carrying trade between Spain and Italy and of the rich Levant trades also climbed steeply (Israel 1989).

40 See Bruijn et al. (1987) for more complete figures on VOC tonnages and cargoes. The numbers of ships are still relatively small, but the values of the cargoes were disproportionately high. 
Batavia (Jakarta) as the Indies entrepôt and headquarters in 1611 and stationed its Governor-General there. Because cotton cloth was the commodity most in demand in the Indonesian spice-producing areas and access to a stable supply would reduce the need for specie, the VOC moved in on the trade in cotton cloth emanating from the south-east Indian coast, soon supplanting the Portuguese in relations with indigenous traders and producers (Raychaudhuri 1962). But the Heren XVII were forced to hold back on their ambitious plans for expansion in the Chinese silk and Ceylon cinnamon trades, and the ruling faction blamed Oldenbarnevelt and the Truce (Elias 1923:39-44). The colonial interest and Amsterdam's efforts to overturn it, joined by Leiden and other manufacturing towns, as well as inland towns in Holland and Zeeland, succeeded in reversing the policy. ${ }^{41}$ The colonial interest was instrumental in the struggles that led to Oldenbarnevelt's execution in 1618 and the renewal of war with Iberia. ${ }^{42}$

The issue was not, it should be emphasized, a lack of state support for longdistance and colonial power and profit. In fact, the States-General had supported the VOC against its own share-holders and its charter at a critical juncture in 1612, enabling the Company to hold off on paying dividends and to begin accumulating a permanent capital. In that same year, the StatesGeneral had contributed toward building a fortified trading post on the Gold Coast of Africa. ${ }^{43}$ The issue was, rather, that the merchants concerned considered the level of support inadequate and the structure of the Dutch state enabled them to act on their perceived interests.

The accession of the colonial interest to power in the States-General and the resumption of the war against Iberia opened the way for an all-out combative colonial strategy in Asia and the Americas. The Heren XVII promoted the imperialist visionary, Jan Pieterszoon Coen, to Governor-General (1619-23, 1627-29). Coen's goals, expanding the so-called country (intra-Asian) trade in order to accumulate a permanent Asian capital and seizing the world spice monopoly, were realized in the seventeenth century. Coen moved aggressively and decisively against indigenous and European competitors. The English in particular, he insisted in 1620, had no right to a single "grain of sand (niet een sandeken) in the Mollucas, Amboina or Banda." 44 With the aim of solidifying the Dutch monopoly, he instigated severely repressive policies against the

41 These towns were now bypassed by goods shipped directly from the Baltic and France instead of via town waterways. While the land provinces did not get higher taxes, they did not get tax cuts either. Israel provides a brilliant historical reconstruction of the economic impact of the Truce (1989:86-101).

42 For a concise English-language history of this period, see Kossmann (1970:371-34). Mosse (1970:176-81) summarizes the religious dimensions.

43 Van den Boogaart (1982:115); Elias (1923:39-44). Extracts from resolutions of the States General, in ARA 1.01.07 \# 1235, \#1237, \#1244, also testify to state support for the company's general goals.

44 The unabashed "grain of sand" letter of May 11, 1620 can be found in the collected writings, volume 1, edited by Colenbrander (1919:543-57, especially p. 544), 
indigenous population of the Spice Islands, culminating in the selective extermination and enslavement of the Bandanese people. ${ }^{45}$ Coen's projects were in a real sense made possible by the dispersed sovereignty inherent in patrimonial political structures, which effectively interposed layers of "plausible deniability" between what he was doing and what the States-General and even the Heren XVII had to acknowledge or could always control. Even the English Ambassador, Ralph Winwood, acknowledged that the VOC "is a body by themselves, powerfull and mighty in this State, and will not acknowledge the authority of the States generally more than shall be for their private profits" (letter to Count of Salisbury, 31 January/10 February 1612, collected in Clark and Eysinga 1940, Vol. 1:51-52). ${ }^{46}$

Meanwhile, the West Indies Company (WIC) was chartered in 1621 and granted a monopoly on trade, transport and product sales in the Americas and West Africa and sovereign rights to make treaties with non-European rulers for twenty-four years. The WIC was conceived as a politico-economic weapon aimed at Iberia, perhaps even more than the VOC at its founding, with closer ties to the States-General, which invested in it and named a representative to the Board of Directors. The WIC's charter explicitly cited piracy as a company mission. The company's five-chambered organization and directorate of Nineteen Gentlemen (Heren XIX) closely resembled the VOC's and were also dominated by Amsterdam, although to a lesser extent than the VOC's. ${ }^{47}$ The WIC mounted a series of ambitious attempts to link the Americas, West Africa, and the Netherlands in a colonial trading network. The WIC survived mainly by privateering, peaking as a pirate enterprise in 1628-29 with the dramatic capture of Spain's annual Mexican silver fleet (an exploit still celebrated in Dutch children's songs). The company was most successful in its post-1637 phase, in which captured territory and sugar plantations in Brazil were linked with sugar markets in the United Provinces and an expanded West African slave trade in the first of the infamous Atlantic triangular trades (driehoekshandel). In 1640, one hundred twenty of the formerly Portuguese sugar plantations were again producing sugar, this time for the Dutch. Renewed productivity was built on the backs of over 23,000 slaves shipped from Elmina and São Paolo (in Angola) to Brazil between 1636 and 1645.48

45 Coen's third goal, bringing out Dutch settlers to be supported with slave labor if necessary, was not broadly implemented in the early modern period. See his plea to the Heren XVII for young Dutch women (jonge meyskens) to populate the colony, also in the letter of May 11, 1620 (Colenbrander 1919:555).

46 For Coen's outrage at, and ultimately successful opposition to, the Heren XVII's efforts to conclude a truce with the English East India Company, see his letter in Colenbrander (1919:543-4).

47 The eighty-three leading shareholders of the Amsterdam chamber invested over one million guilders, one-third of the city's total, but a high proportion of investment in that chamber came from outside the city, compared to the VOC. For the founding of the WIC, see Menkman (1947:42-6), Goslinga (1971:90-3), and Van Dillen (1970:146-9).

48 For this phase of WIC history, see Emmer (1972), Van den Boogaart (1982:116-27), and Van Dillen (1970:153-7, 160-1). Postma's (1990) is the most thorough analysis of the Dutch 


\section{INTERCORPORATE STRUGGLE AND PATRIMONIAL ELITE DIVISION}

The capacity of patrimonial states to formulate and execute decisions rested on the organization and resources of corporate groups (and on the instruments that the state had to regulate their activities), as well as on the state's own institutions. The relationship between states and chartered mercantile and colonial companies was especially important in this context. When the companies were successful, as the VOC in particular was, they established a degree of political autonomy, making the relationship between them and their home states complex and contested. "It is surely true to say that the Dutch East Indies Company is not only a trading company but also a state," remarked the Dutch statesman and company director, Coenraad van Beuningen, in about 1684 . His remark aptly captured the corporation's sovereign power and its fused politico-economic character. Seen from the perspective of rulers, the structure of patrimonial rule therefore entailed a worrisome degree of insubordination. Conversely, from the perspective of merchants and investors, this structure made for operational unpredictability. The companies' right to operate was contingent on the state's renewal of company charters, a renewal that was never guaranteed. Although these tensions diminished when the monarch was subordinated to the estates and merchants or manufacturers controlled the levers of estatist rule, as in the Netherlands, the problem never vanished.

Here again, the world-system concept of states in global interrelationship fails to grasp the genuine impact of patrimonial corporations and segmented sovereignty on the developing system and on the states that were evolving within it. Chartered companies, like other powerful corporate bodies, joined towns, provinces, and other corporations in jockeying for position and struggling to define themselves politically within an emergent structured totality, the interstate system. ${ }^{49}$ Whereas world systems theorists consistently stress the necessary functionality of interstate competition for the preservation of the world system (although they have so far failed to specify the mechanisms that guarantee that state of affairs), I am emphasizing the social-structural contradictions and contestation that take place at the macro-institutional level. ${ }^{50} \mathrm{We}$

slave trade. Hall (1991) analyzes colonial Brazilian agriculture as a patrimonial political economy from a neo-Weberian perspective critical of world-systems theory. Also relevant is Stern's opening salvo in his debate with Wallerstein, "Feudalism, Capitalism, and the World-System in the Perspective of Latin America and the Caribbean" (1988).

49 Both Giddens (1986:301) and Tilly (1990) note that corporate bodies made sovereign claims in early modem Europe. In my view, however, they greatly underrate the historical impact of that fact.

50 For example, Hopkins writes of the system: "What marks it is this: the alignments or sides are so formed on each occasion ("balance of power") as to reproduce, as the outcome of conflict, the necessary condition for the state-system to continue to operate, namely, an array of interrelated states no one of which can mobilize the force and allies needed to subjugate all the others (thus preserving the development of the modern world as a world-economy by blocking its conversion into a world-empire)" (Hopkins 1982:24-25). 
can expect the presence of multiple centers of sovereignty only partially regulated by overarching norms or a central power to introduce distinctive pressures, both for the Netherlands and for the world-system as a whole. We can also expect that, for a patrimonial politico-economic system to be successful in the long run (and in the limit case, hegemonic), a state's spin-off corporations and companies have to work in tandem with one another and with their home state, as well as being effective against other states and their corporations. This is a difficult equilibrium to achieve. My analysis in this section thus focuses on intercorporate interactions, which were only gradually organized and subsumed under state-to-state networks and which were an integral feature of the precarious and evanescent structural balance underpinning Dutch hegemony.

The pressures of war weighted the scales against the West Indies Company. As the contest with Spain dragged on, it became harder for carrying traders to obtain salt for fish preservation and wool for the textile industry. Naval attacks and privateering in the Baltic affected the availability of the naval supplies that advantaged Dutch shipbuilders and, thus, freight rates. The war also hurt merchants engaged in the essential trade in grain (Christensen 1941:377-8; Den Haan 1977:150). As early as the 1633 negotiations, the Amsterdam town council began instructing its deputies in the Holland States to agree to Dutch withdrawal from Brazil. Amsterdam merchants became increasingly vociferous in the cause of the carrying trade. One hundred fifty-nine of the city's large-scale traders lodged a protest in the States-General in 1641 regarding the diversion of funds away from the defense of European trade, and they called loudly for free-that is, non-company-trade in the West Indies.

Why did the Amsterdam City Council, once the staunchest promoter, lose its enthusiasm for the West Indies Company? Part of the answer lies in the uppermost faction in the council (vroedschap): the Bicker family and its clients, which blended European carrying trade interests with an orientation to East Indies expansion. They came to the fore in the late 1620 s and ruled "not only the seas and the Amsterdam exchange but also the Town Hall" (Roorda 1964:124) for a quarter-century thereafter by patronage and marital alliances which embraced other influential merchant-regent families. The mercantile holdings of the Bickers themselves spanned the globe, consolidating a new level of unity of merchant capital, finance, and government in Amsterdam. Gerrit, a town councilor from 1590 until his death in 1604, served many local governmental functions. A founder of the precompany, The Far Lands Company, and a founding investor in the VOC, he took part in a 1597 trading effort to America and Peru and one to Northern Russia. His sons continued the tradition of far-flung involvements. Andries, a vroedschap member from 1622 to his death in 1652, was Amsterdam mayor for many terms, overseer of the Wisselbank, representative to the Admiralty and States-General, and ambassador at various times to the Swedish, Polish, and Brandenburg courts, as well as a trader in spices and Russian furs. His brother, Jacob, was a VOC 
director from 1610 to 1641 , while Andries himself served from 1641 to 1652 . The third son, Jan, was a well-known merchant involved in Italian and Levant trades and shipbuilding. The Bicker clan had also been an early supporter of the WIC, and Gerrit's fourth son, Cornelis, was appointed a director in 1622. In 1629, however, the Bickers sold their shares, disengaged themselves from the company, and began competing against it in Brazil-based commerce. Thus, the Amsterdam City Council's connection with the WIC was attenuated after 1630, when the council strongly favored free trade to Brazil, including the opening of the lucrative slave trade, for all Dutch merchants. ${ }^{51}$

The accumulation strategies of the WIC increasingly diverged from those of the Amsterdam carrying traders and West Indies interlopers, as expressed by delegations from these groups and the Amsterdam city council. Now the East Indies Company turned against the WIC as well. There had been prior strains and competition for military resources between the companies. To give just one serious example: The WIC lost Bahia, the capital of Brazil, to the Spanish only a year after having captured it in 1624 because WIC naval reinforcements were diverted by the States-General to blockade the Iberian coast and to protect VOC shipping (Goslinga 1971:148-52). But now the divergence was more marked. The VOC, which was shipping over a million pounds a year of Chinese sugar from its base in Formosa (Taiwan) by the 1630 s, faced competition from rising sugar production in Dutch Brazil. By the early 1640s, this competition was cutting into the VOC's trade, which surged again after the WIC's ouster (Harrison 1970:659). The Heren XVII had also stopped opposing peace with Spain, now that they were sufficiently established in the East Indies to set their own conditions for compliance..$^{52}$ Finally, the VOC was faced with a proposal of merger raised by the WIC and supported by elements of the States-General, which the company disliked and eventually eluded. It was in this context that the Heren XVII made their famous and characteristically patrimonial remark, or threat, that the East Indies belonged to the VOC, not to the States-General, and could be sold for profit to the Spanish or to any other enemy of the state. 53

The drop that made the bucket overflow (to employ a well-worn Dutch

51 Long ago, Boxer (1957:255-8), seconded by Goslinga (1971), noted that the Bickers' actions undercut Amsterdam's support for the WIC. This is not to say, of course, that all Amsterdam merchants followed the Bickers' lead and summarily abandoned the company; some Amsterdam merchants actually increased their investments at that time. My point is, rather, that the Bicker family's and Amsterdam vroedschap's change of line influenced the state's overall support for the WIC's commercial system.

52 The Heren XVII's conditions advised the States-General in 1644 and 1645 that if peace were to be made, Spain had to agree not to extend its forts and trade beyond current limits or to take any Portuguese possessions (Israel 1982:334-6).

53 The VOC's charter had expired in 1643, and renewal was held up by the WIC's efforts to secure its position by fusing with the VOC, as well as by the demands of several towns that they be allowed their own chambers in the company. The VOC agreed to admit representatives from these towns to existing chambers but staunchly opposed the merger (Van Rees 1868:209-10; Van Dam 1927 [1701], vol. 1:43-72; Van Dillen 1970:127). For the WIC directors' merger proposal, see the documents in ARA $1.04 .02 \# 4652$. 
metaphor) was a rebellion by Portuguese colonists in Brazil. The colonists protested the monopoly prices of imported European goods and slaves and the falling prices of their own sugar and dyewood exports in Europe by rising up against the company's temporarily reduced forces and driving the WIC out of the capital in 1645 . One can speculate, in the grounded historically counterfactual vein, that had the Heren XIX's efforts to encourage colonization paid off or had the company's policies vis-à-vis the percentage of surplus that was to remain in the sphere of production been less grudging, tensions within the Brazilian colonial elite would have been eased, and the revolt might have been defused or defeated. ${ }^{54}$ They were not eased and the revolt was not defused, however; and the WIC was forced to seek state subsidies and military support to regain its prize.

At this juncture the shift of the Amsterdam mercantile elite's support away from company organization in the Atlantic zone proved critical for the WIC's fate. The Amsterdam vroedschap and VOC directorate, extensively overlapping categories to be sure, sabotaged the WIC. For a decade after 1645, I believe, the company could have won back Brazil if it had received a modicum of the economic and military support that the state was capable of providing. Portugal was a puny sea power compared to the United Provinces, and the Portuguese state was divided over what tack to take with the colonists (Prestage 1925:205; Van de Haar 1961). The WIC was thwarted not so much by the rebellion as by Amsterdam's and the VOC's refusal to provide the resources to counter it. The company did not receive the subsidy and armed support voted by the States-General because of Amsterdam's, and Holland's, opposition (Van Dillen 1970:157; Israel 1982:371-3). The VOC administered the coup de grace in 1653 by refusing an offer from the Portuguese, backed by the WIC and the Dutch States-General itself, to exchange some East Indies conquests of Portuguese possessions for the WIC's Brazilian claims (Prestage 1925:214-5). Thus, the Portuguese were able to oust the WIC from its last outposts in Brazil in January 1654. After that, the WIC was neither an effective mercantile enterprise nor an instrument of war (Van den Boogaart 1982:134-44). 55

Historians have debated whether or not the absolute burden of debt made it impossible for the Dutch state to intervene in favor of either the WIC or of a more broadly interpreted Dutch Brazil. It is true that war costs were high. 56

54 From 1642, the WIC tried to foster Dutch emigration; but the number of Dutch agricultural settlers remained only a few hundred. Most of the 3,000 in 1642 were merchants and officials (Van den Boogaart 1982:123-4).

55 The Dutch Republic renounced its claim to Brazil at the conclusion of the war with Portugal in 1661 .

56 As Marjolein 't Hart (1993) notes, the companies had been a key factor in driving up the central public debt from 4.9 million guilders in 1617 to 13.2 million in 1648, and Holland's more important provincial debt from 1.5 million in 1621 to the startling figure of 130 to 140 million in 1650. 'T Hart's book, explicitly inspired by Tilly's (1990) theoretical stance, deals with the important relationship between war and the early seventeenth century Dutch fiscal system. 
Yet in the 1660s the state had no difficulty finding more subscribers for the loans it sought. It should also be pointed out that Amsterdam's town council armed a fleet of 150 warships with funds from the Stock Exchange at the direction of the city regents and used the fleet in the preliminaries to the first Anglo-Dutch War in 1652. The council was also able to intervene aggressively in the war between Denmark and Sweden (1656-59) to protect its northern trade and to mount an extensive expedition to the west coast of Africa in 1664 that precipitated the second Anglo-Dutch War (Elias 1923:139). ${ }^{57}$

It is, therefore, more reasonable to draw the historically counterfactual conclusion that the Amsterdam merchant-regent elite was capable of mounting a defense of the WIC and Dutch Brazil but chose not to in the face of the more traditional mercantile and what it regarded as the more compelling interests of the European carrying trade and East Indies Company. The VOC in particular was able to make that decision stick because the States-General lacked any sovereign mechanism by which it could enforce immediate compliance on its patrimonial corporations. If the pressures of interstate war and colonial rebellion weighted the scales against the WIC, Amsterdam and the VOC tipped the balance.

Thus, the patrimonial state/corporate system engendered intercorporate struggles that caused the first cracks to appear in the international commercial system organized around the Netherlands as an active entrepôt trader. Furthermore, the patrimonial state and its corporate configuration restructured the linkages between overseas trade and colonial production in the Atlantic territories, specifically plantation agriculture based on slavery, in ways which affected the Netherlands' ability to sustain that trading system, and hence the hegemonic moment. The loss of Brazil deprived the Dutch of an agricultural zone for settler plantations which could match the eventual production levels of the English and French possessions and serve as a politically secure home market, thus cushioning economic reverses for Dutch merchants when other metropolitan countries began to enforce increasingly protectionist measures. The comparatively poor economic performance, and eventual failure, of their truncated plantation holdings undercut the Dutch share in the Atlantic multilateral trade. ${ }^{58}$ Perhaps even more consequential for future domestic politicoeconomic development, the ties between planters and colonial-interloping and other independent traders were abrogated. These ties had grown up in Brazil within the shell of the WIC, and the company's ill fortunes permanently disrupted them. In an actually existing "historical counterfactual" instance,

57 In which war, it should be noted, the VOC played its part. See the documents in ARA 1.04.02 \#4723 regarding the contemporaneous squabbles between the VOC and the English East India Company.

58 For the Dutch, see Emmer (1982:150-5). Postma (1990: ch. 12) reviews the final years of the Dutch slave trade. For the contemporaneous expansion of French colonial trade, see Butel (1990) and Boulle (1972:71-74). Wilson (1965:264, 271-2) discusses the slippage of the Netherlands' relative position vis-à-vis England in the Atlantic during the eighteenth century. 
analogous linkages would become a key basis for English commercial expansion in the Atlantic zone. 59

\section{HEGEMONY AND THE SEEDS OF DECLINE}

At first glance, the midpoint of the seventeenth century was a time of brilliant success and consolidation for Dutch hegemony. The Golden Age seemed at its most lustrous. The Eighty-Years War with Spain concluded with the Peace of Munster (1647-48), a resounding victory for David over Goliath. The year 1650 marked Stadholder William II's failed coup and the inception of the first Stadholderless Era (1650-72), in which the Amsterdam merchant-regent elite guided policy jointly with Grand Pensionary Johan de Witt. The Dutch world-trade and financial system looked as healthy and stable as ever. ${ }^{60}$ In the Atlantic region, Brazil was lost, but the Netherlands eventually controlled several Caribbean islands and parts of the Guiana coast. The Dutch West Indies Company was partially reconstituted and transformed into the Second (Tweede) WIC, retaining rights (until the 1730s) to supply the remaining Dutch colonies with slaves. ${ }^{61}$

In the Pacific, the 1650 General Instruction (Generaal Instructie) from the VOC directors to central Asian headquarters in Batavia codified the strategic and organizational principles that would form the linchpin of Dutch colonialism for the next century. ${ }^{62}$ Where the VOC had made conquests or signed monopoly "contracts" with Asian rulers, the company was to continue restricting the supply of key commodities to keep their sale prices high. In the Spice Islands, the core of the VOC territory, this strategy entailed continuing the harsh policies regulating the involvement of Asian merchants and rulers, eliminating other European contenders, and limiting the production of indigenous producers. The company swept Asian traders out of some areas, such as the Java Sea and Ceylon coast, and restructured trade patterns according to company dictates in others. In what would prove a crucial move, the VOC

59 For these linkages, see Van Dillen (1970:153-5). Regarding the role of analogous ties for England, see Brenner (1993: ch. 4, especially 159-66, and ch. 12). Merchant supply of slaves and the labor processes characteristic of plantation slave economies were closely entwined, since extending cultivation by means of adding more slaves was the prevalent form of expansion, as shown by Van Zanden's figures on the relationship between numbers of slaves and development of plantation agriculture in Dutch Surinam (Van Zanden 1991: ch. 5).

60 See Israel (1989:197-291) regarding the health of the system around 1650. Israel argues that Dutch commercial dominance lasted until after 1720 . In contrast, on the basis of a combination of ratio and proportion measures of the Netherlands' share of global trade, Misra and Boswell (1993) put the end of Dutch hegemony in the late 1660s to early 1670s. They note, however, that their global trade measure is keyed to the number of ships rather than cargo values and is highly influenced by the larger numbers of ships with comparatively low-value cargoes in the Baltic trades.

61 After that, it became a "body without a soul" (Emmer 1981:82). Emmer's fine article argues that the WIC's post-1640s turn away from making war was a rational adaptation for the company (1981:95). This essay adopts a different position, arguing that the "rationality" and outcome of the transformation must be evaluated with respect to the entire Dutch trading system and not simply the WIC itself.

62 See van der Chijs (1886:135-57) for a copy of this document. 
successfully banned private trade by Dutch merchants in commodities of concern to the Company. Lastly, the VOC destroyed "excess" trees and converted direct producers into sharecroppers and, on occasion, slaves (Furber 1976:50-52). These policies were undoubtedly effective. By the 1660s, the Company controlled the trade between Europe and Asia in spices and dominated the relevant 'country' (intra-Asian) trade. These achievements underlay the huge increase in the quantity of VOC trade and profits during this period. ${ }^{63}$

But amidst this cornucopia lay prospective problems. The most obvious and oft-noted came from other European contenders envious of the Dutch trading system and desirous of sharing in more of its fruits. ${ }^{64}$ The Netherlands faced increasing competition, as other states, merchants and chartered companies emulated their Dutch counterparts, appropriating their politico-economic innovations, including shipbuilding and navigation techniques, forms of business and bank organization, agricultural advances, and of course the triangular trade system. Competitor states also began to apply novel protectionist measures backed by mercantilist aggression. In what was but a foretaste of events to come, English merchants prevailed upon the Commonwealth state to pass the first of the protectionist Navigation Acts in 1651; together with the seizure of 140 Dutch ships at sea, this action ignited the first Anglo-Dutch War (Brenner 1993:625-8). ${ }^{65}$ Perhaps most ominously, the simultaneous and at times collaborative attempts by England, France, and other states and corporations to undercut Dutch influence formed a kind of pincer movement that culminated in repeated wars and an attempted invasion in the so-called Disaster Year (Rampjaar) of 1672. These are essentially the factors stressed by world-systems theory and, recently, by historians, such as Jonathan Israel: the diffusion of technical and organizational innovations, merchant struggles over trade, and interstate rivalry with an eye to securing commercial advantage, which at that historical juncture involved challenging the ubiquitous Dutch middleman. ${ }^{66}$

63 In 1621 , it had 67 ships in the Indies seas; in 1664, over 140. For the general increase in profits, see Table 11 in Gaastra (1982:119). The VOC consolidated its hold further by the 1680s. From its center at Batavia, it traded in Indonesian spices; Chinese, Persian, and Indian silks; Japanese copper; Indian sugar, and other commodities. See Gaastra (1982:37-52, 104-5, 10918), Arasaratnam (1987:124), and Furber (1976:42-64, 268-72). The company also founded the first colony in South Africa, at the Cape of Good Hope, in 1652. Boxer (1965:273-301) provides a summary in English.

64 The envy owed something to contemporary mercantilist doctrine, which understood world trade as a zero-sum game. See Heckscher (1955, vol. 2:23-26). Another important factor may have been the constraints on European markets imposed by feudal restrictions that were still prevalent in many areas of Europe (Brenner 1985).

65 Although this first wave of English and French protectionism did not always accomplish its stated ends (see Israel 1992), it served as a model for the formidable series of protectionist measures adopted in the early eighteenth century by Scandinavia, Russia, Prussia, Austria, and other states. See Heckscher (1955, vol. 2:112-72).

66 See Wallerstein (1974: ch. 5) for an argument that Dutch hegemony ended when England (and to a lesser extent, France) caught up technically and organizationally. Israel (1989: ch. 7) argues for the importance of other European states' protectionist policies and military initiatives in the demise of Dutch hegemony. 
International politico-economic pressures created by the rise of competitor nation states in conjunction with the sunk costs inherent in a vulnerable entrepôt role were certainly important causes of Dutch downfall. But they were by no means the whole story of either the loss of hegemonic position or the subsequent decline. Patrimonial structures of rule were also important causal mechanisms and can be said to have contributed in several distinct ways.

First, as the previous section made clear, patrimonial company structure and intercorporate struggles undermined the Atlantic branch of the commercial-colonial system, although the extent of the damage only became clear in the context of increasing English and French competition. Dutch merchants and the Dutch state were still able to make money out of the West Indies: As late as 1750-74, Amsterdam, Rotterdam, and Zeeland derived an annual average revenue of over 10 million guilders from Surinam imports alone (Goslinga 1985:217-23). But the Netherlands lost their position at the leading edge of commercial-colonial expansion, which had shifted decisively to the Atlantic in the latter half of the seventeenth century.

In the Pacific, the patrimonial distribution of privilege among politically constituted corporations also took its toll. There the overwhelming success of the VOC's fused politico-economic structure imposed its own limits on Dutch development. Once a source of dynamism, that structure eventually prevented the company from harnessing the ascending and ultimately victorious forces of private trade. In the Dutch company's bailiwick, private trade continued to be severely curtailed, in spite of a drop in the VOC's country-trading fleet from 1690 to 1740 . The VOC asserted its monopoly rights to both the country trade and the Europe-Asia route. The enforcement of the intra-Asian monopoly kept the number of Dutch private country ships at ten or fewer per season between 1713 and 1743 (Furber 1976:275). This may not have damaged the company's trade in absolute terms but did so in a relative sense, for the English East India Company's intra-Asian trade far outstripped the VOC's in the eighteenth century. The VOC missed out on new commercial opportunities, notably the burgeoning tea trade, which was captured by the EIC instead (Furber 1976:126). To add insult to injury, VOC employees began to smuggle goods for private profit with the EIC's help (Furber:275-83). By 1796, the English proportion of European country trade was estimated at 90 percent of the total traffic (Watson 1980:85). Too much intercorporate struggle had helped defeat the Dutch West Indies Company; overconsolidation hampered its East Indies counterpart.

Patrimonialism also placed strict limits on the further development of the Dutch state's capacity and, therefore, on the elites' ability to address the politico-economic decline after the loss of hegemonic position. ${ }^{67}$ As we have seen, privileges, including offices, drew particularistic elites, groups, com-

67 The debate over whether the eighteenth-century Netherlands declined absolutely or relatively to other countries is an extensive one and need not be dealt with here. For the debate, see Adams (1990). 
munities and regions into the ambit of the state; and elites were politically identified with, and sovereignty anchored in, local councils, provincial states, and chartered companies. The regents buttressed and built on the existing structure, subscribing mainly to local and provincial government loans (Riley 1980:68-82; Fritschy 1988: ch. 1) and creating new offices and privileges that were locally, at most provincially, focused. ${ }^{68}$ The spatial crystallization of privilege constructed the solidarity and integration that defines a nation along predominantly local lines (citizenship, for example, remained a local status, awarded by urban burgomasters, throughout the period under examination).

This estatist structure inspired foot dragging in policy making. The tendency of the Dutch state toward temporizing played its part in handing England's Tory Party large politico-economic concessions in the Treaty of Utrecht (1715), which concluded the expensive War of Spanish Succession, codified competitors' permanent inroads into the Dutch entrepôt, and "marked a significant step towards Britain's supplanting of the Dutch as the world's dominant commercial power." 69 The structure also encouraged competition and squabbling among component parts, not only between the East and West Indies Companies, and among locally based arms of those bodies, as we have seen, but also in other areas. Particularly relevant to the incapacity to address longrun commercial-colonial problems was the competition among the five overlapping naval admiralties, run by the regents and their provincial representatives. When the threat of war and pressures on the entrepôt worsened in the early eighteenth century, each admiralty responded by lowering its customs rates, hoping to lure away trade from other localities. This contributed to falling revenues, scarcer funds for the navy, and a decline in military readiness. ${ }^{70}$ In general, the eighteenth century saw sustained intercorporate conflicts over the entangled issues of the decline of trade, foreign policy, and public finance. The struggles within Holland prevented Amsterdam and the province from assuming their traditional leadership role (Porta 1975). The resulting insolvency of the Dutch treasury enforced a policy of neutrality vis-

68 Amsterdam mayors controlled the allocation of more than 3,200 subaltern offices by the mid-eighteenth century (Bussemaker 1907), compared to the relatively low total of central state offices, an estimated 100 to 200 in the early seventeenth century and only 300 in 1800 , with some of the new officers appointed and paid by the provinces ('t Hart 1993:197). Elsewhere (Adams 1994), I argue that the desire to protect patrimonial lineage property and family reputation was an important motivation driving locally focused development.

69 The quote is from Israel (1989:375). Veenendaal (1980:19-27) provides a useful summary of the Dutch position in and reaction to the Spanish Succession War.

70 For estimated costs of the duplicate admiralty system, see 't Hart (1993:205-6). Historians' estimates of evasions of the customs in the early eighteenth century range from 30 to 40 percent in Amsterdam and Rotterdam to almost 80 percent in Zeeland (Joh. de Vries 1958: Westermann 1948). The rate of evasion appears to have risen as well (Joh. de Vries 1958:225-6). Fritschy discusses the falling customs intake (1988:35). The customs are of most interest here because of their direct impact on naval readiness, but note that the excise (gemeene middelen), the other important indirect tax, was subject to similar problems during this period (Aalbers 1977). On naval defense as an apple of discord and on its poor funding in the early eighteenth century in the Republic, see Bartstra (1952: ch. 1). 
à-vis the other European powers from 1713 to 1795 (Carter 1975). Whether or not this was the most reasonable policy, the point is that the patrimonial nexus of state and merchant elite foreclosed other options.

This fallout from estatism was less of a problem while other European states were similarly organized. For a long while, in fact, the Netherlands held the advantage as a merchant-controlled body, rather than one in which the Crown dominated the estates and an agrarian seigneurial elite appropriated patrimonial state offices (as in France or Spain) or in which the uneasy balance between the Crown and estates and the plurality of elites contending for a piece of politico-economic privilege made for an erratic history of supporting trade (as in pre-revolutionary England). But toward the end of the early modern period, when England in particular moved beyond patrimonial rule, this was no longer the case.

These limits to Dutch state capacities were overdetermined by another consequence of patrimonial rule: The possession of patrimonial privileges changed the class character of the regent elite that held them. The dominant merchant class may have captured the Dutch state, but state structure and policies in turn restructured the perceived goals and interests of the governing elite along the lines of rentier capitalism. ${ }^{71}$ This is one further reason, contrary to the expectations of the world-systems model, why ruling elites in the Netherlands and elsewhere cannot simply be assumed to deploy and restructure states at will, institutionalizing bureaucracies, military rationalization, and public finance because they favor the development of trade. That the Dutch elite failed to carry out many of these reforms was in part due to the fact that they were no longer merchants, so their perceived economic, political, and familial well-being had come progressively uncoupled from the immediacies of trade. The more abstract point relevant to world-systems theory is that social roles and patterns of institutional and oppositional action should not be conceptualized as functionally impelled by systemic logics: They evolve, even within fixed functional limits.

The Dutch position in the East Indies was the most enduring pillar of the Netherlands' world trading system and its global politico-economic power. ${ }^{72}$ Until the mid-eighteenth century, impressive economic and political inputs

71 Whereas Amsterdam councillors and mayors had invested a negligible amount in state bonds in 1600 , a century later they were placing half of their wealth in bonds, mainly issued on Holland's public debt (Burke 1974). The regents of other towns for which information is available evince similar characteristics, with some variation according to the position of the town in the regional division of labor. On the general shift of the regency from trade to rentier capitalism, see Roorda (1964) and Van Dijk and Roorda (1971). With regard to the correlative movement inside the VOC directorship, see Adams (1990).

72 The market value of goods shipped from the East Indies, goods then re-exported throughout Europe, which had totalled 8.7 million guilders in 1648 to 1650 , topped 23 million in 1738-40, and 28.1 million in 1778 (Glamann 1958:14). Besides pepper and spices, for which the VOC continued to set European prices until the 1740s, European demand skyrocketed for tea, coffee, and raw and processed silk and cotton. See Gaastra (1982). 
continued to flow from the VOC to the state, including 3 million guilders for the charter renewal of $1700-40$ and over 400,000 guilders to the admiralties throughout the century (Gaastra 1982:148; De Korte 1984:6-8). Even the VOC, however, was severely stressed by mid-century. The Safavid dynasty in 1722 inaugurated a long period of dynastic struggles and instability in the Indian subcontinent, on which the EIC eventually capitalized with the aid of English and Dutch private traders. In the end, Pacific colonial strength, hollowed out from inside, ended with a bang rather than a whimper. The VOC's sovereign authority lapsed, notably in Bengal in 1759, when the Company sabotaged itself with an incompetent defense against English incursions, and in the fourth Anglo-Dutch War (1780-84). When the VOC appealed to the Dutch state for military support, the state was not able to muster an adequate fleet in defense. The VOC lost its key base on the Coromandel coast to the English. The total financial loss amounted to a staggering 60 million guilders. The directors had to suspend payment on loans and became completely dependent on the state for credit (Steur 1984:155-7). Infusions of cash came from the States of Holland and from Amsterdam's town council. But by 1783, the spice monopoly was gone; and the English had secured de facto free trade in the Eastern seas. ${ }^{73}$ The fusion of politico-economic privilege and local elite goals had rendered the emergent Dutch state incapable of countering the strategic myopia of its leaders.

\section{CODA}

The ground-breaking world-systems paradigm raises excellent questions about the source of the advantaged position of metropolitan countries, but, as I have tried to show, the answers it returns are inadequate. To sum up, very briefly, the Dutch case demonstrates that the "strong state" defined by Wallerstein was not essential to securing the hegemonic position. Furthermore, and here we step decisively out of the world-systems paradigm, the state may be efficacious with respect to a particular commercial-colonial project; but the relative efficacy of that project cannot be defined in terms of its ultimate global success, as world-systems theory defines it, else we have mere theoretical tautology. This essay has proposed that we substitute a macro-level, middle-range theory for the world-systems model, deriving the fundamental properties and dynamics of the subunits not from their functional location in the whole but from the configuration of unevenly developing social structures and the struggles that took place within and about them. ${ }^{74}$ In this reading, the social relations within the Dutch commercial-colonial system, those linking company merchants with global monopolistic ambitions, merchant interlopers fighting for a piece of the trade, and agrarian producers operating in a slave

73 See Dillo (1992) and Van Eyck van Heslinga (1988) regarding the end of the sovereign company and the fate of its remnants up to 1806 .

${ }^{74}$ On the desirability of theories of the middle range, see Merton (1967:39-72). 
mode of production are seen to be contested and causally consequential. But this article has focused more particularly on the role of an historically specific interaction of patrimonial state and merchant elite in the rise of the Netherlands and on the precarious but conjuncturally effective relationship of mutual support between the Dutch state and its satellite corporate bodies, notably the East and West Indies companies. Conversely, I have argued that the developing contradictions and conflicts among those corporate satellites and the Dutch state undermined the Atlantic component of the commercial-colonial system. This and other long-term consequences of Dutch estatist patrimonialism contributed to the loss of hegemony and subsequent decline of the early modern Netherlands.

The inclusion of the patrimonial nexus of the state and elites as an explanatory factor can also clarify differences in the developmental trajectory of other areas or countries, notably England, a country that was in many respects economically similar to the Netherlands. In England, the balance between the Crown and estates prior to the Civil War and the plurality of elites contending for a share of state privilege inhibited the dominance of any single elite. Because elite power was more dispersed than in the Netherlands, a situation reinforced by patrimonial strategies, the state could not be permanently captured by any one class or faction. This was reflected in the history of the East India Company, which logged an erratic history of support and attack from both the Crown and Parliament before the Glorious Revolution, while facing competition from the increasingly established Dutch company. Its performance was correspondingly uneven.

But the shift beyond patrimonialism, confirmed by the Glorious Revolution of 1688-89, forged new limits under which state apparatuses were formed. After this point, patrimonial corporations, such as the East India Company, existed in increasing tension with newer state structures and with the executive's exercise of statutory control over commercial-colonial policy. In contrast to the early modern Netherlands, I would argue, state differentiation and integration endowed English commercial and colonial policy with greater capacity and flexibility. It did so by means of several mechanisms. Patrimonial corporations were replaced by statutory rule financed by taxing private individuals and partnerships, while venal office-holding was displaced by bureaucratically organized offices on the one hand and a party patronage system which supplied incumbents to fill them on the other. State restructuring not only supplied the political and military conditions for a higher rate of mercantile profit but also guaranteed that a higher percentage of profits would reach the public exchequer. By these means, even convinced, isolationist Country Tories could be induced to pay for an expensive "blue water policy" which underwrote the country's increased naval might. 75

75 For the blue water strategy, in which "the military weight of the Continental powers was to be opposed by naval skills, superiority of equipment, and abundance of money and resources, as well as access to resources," see Baugh (1987:87-88). The English navy doubled its tonnage 
The East India Company, as a transitional corporation embedded in state power and finance, was both a part of and increasingly at variance with the new thrust of rule. That incompatibility reached a tipping point with the inception of the Company's territorial rule and the resulting expansion of its patronage and threat to its commercial and imperial stability. On the basis of the integrated rule and expanded capacity that it had attained, Parliament was able to begin to establish state sovereignty over the EIC - and therefore India - and to nationalize and bureaucratize its structures. Under these unique conditions, the dynamics of patrimonial state-merchant capitalism spurred empire building, manufacturing capitalism, and state formation in the metropole. Only then may patrimonial corporations like the East India Company be said to have acted as a "forced draught" fanning metropolitan development, as Eric Hobsbawm metaphorically speculated (1967:46-7, 53-6), rather than as a blast of chilly air inhibiting moves beyond traditional politico-economic organization, as was the case in the Netherlands. ${ }^{76}$

from 1714 to 1760 , deploying up to 10,000 men in peacetime and over 100,000 at the time of the American War (Brewer 1989:33), in contrast to the Dutch navy, which was increasingly undermanned, underequipped, and relied on relatively backward technology during this period. The classic source for the Dutch is De Jonge (1855-62, vol. 4:1-440).

76 Ironically, the Netherlands contributed to its own displacement as hegemon, by means of the mechanisms outlined in this essay, of course, but also by providing plenty of cold cash. The English state increasingly depended on loans from Dutch citizens, estimated in 1776 to account for fully 59 million pounds of the total national debt of 143 million pounds. Thus Wilson says, "With the borrowed profits from Holland's Golden Age, Britain gambled on an imperial future, and gambled successfully" (1949:161).

\section{REFERENCES}

Aalbers, J. 1977. "Holland's Financial Problems (1713-1733) and the Wars against Louis XIV," vol. 6 of Britain and the Netherlands, A. C. Duke and C. A. Tamse, eds., 79-93. The Hague: Martinus Nijhoff.

Adams, Julia P. 1990. One's Company, Three's a Crowd: Merchant Companies and State Formation in the Early Modern Netherlands, France and England, 16001800. Ph.D. Disser., Department of Sociology, University of Wisconsin-Madison. 1994. "The Familial State: Elite Family Practices and Statemaking in the Early Modern Netherlands." Theory and Society, 23:4.

Algemeen Rijksarchief (ARA), The Hague, Netherlands. Archives of the VOC 1.04 .02 \#4652, \#4723.

- Archives of the States-General 1.01.07 \#1235, \#1237, \#1244.

Arasaratnam, S. 1986. Merchants, Companies and Commerce on the Coromandel Coast, 1650-1740. Delhi: Oxford University Press.

Aymard, Maurice, ed. 1982. Dutch Capitalism and World Capitalism. New York: Cambridge University Press.

Baelde, M. 1988. "De Nederlanden van Spaanse erfopvolging tot beeldenstorm, 1506-1566," in De Lage Landen van 1500 tot 1780, I. Schoffer et al., eds., 38101. Amsterdam: Agon.

Barbour, Violet. 1963 [1950]. Capitalism in Amsterdam in the 17th Century. Ann Arbor: University of Michigan Press.

Bartstra, J. S., Jr. 1952. Vlootherstel en Legeraugmentatie, 1770-1780. Ph.D. Disser., Department of History, University of Leiden. 
Baugh, Daniel. 1987. "British Strategy during the First World War in the Context of Four Centuries: Blue Water versus Continental Commitment," in Daniel M. Masterson, ed., Naval History: The Sixth Symposium of the U.S. Naval Academy. Wilmington, Delaware: Scholarly Resources.

Blockmans, W. P. 1978. "A Typology of Representative Institutions in Late Medieval Europe." Journal of Medieval History, 4:2 (June), 189-215.

Boogman, J. C. 1979. "The Union of Utrecht: Its Genesis and Consequences." Bijdragen en Mededelingen Betreffende de Geschiedenis der Nederlanden, 94:3, 377-407.

Boswell, Terry; Joya Misra; and John Brueggemann. 1991. "The Rise and Fall of Dutch Hegemony: Evidence from the Baltic Sound Tolls," in Cities in the WorldSystem, Resat Kasaba, ed., 55-80. New York: Greenwood.

Boswell, Terry, and Joya Misra. Forthcoming. "Cycles and Trends in the Early Capitalist World-Economy." Review.

Boulle, Pierre. 1972. "Slave Trade, Commercial Organization and Industrial Growth in Eighteenth-Century Nantes." Revue Française d'Histoire d'Outre-Mer, 59:214, 70-112.

Boxer, C. R. 1957. The Dutch in Brazil 1624-1654. Oxford: Oxford University Press. 1965. The Dutch Seaborne Empire, 1600-1800. London: Penguin.

Brenner, Robert. 1993. Merchants and Revolution. Commercial Change, Political Conflict, and London's Overseas Traders, 1550-1653. Princeton: Princeton University Press.

_ 1985. "The Agrarian Roots of European Capitalism," in The Brenner Debate: Agrarian Class Structure and Economic Development in Pre-Industrial Europe, T. H. Aston and C. H. E. Philpin, eds., 213-327. Cambridge: Cambridge University Press.

_ 1977. "The Origins of Capitalist Development: A Critique of Neo-Smithian Marxism." New Left Review, no. 104 (July-August), 25-93.

Brewer, John. 1989. The Sinews of Power. War, Money and the English State, 16881783. New York: Alfred A. Knopf.

Briels, J. 1985. Zuid-Nederlanders in de Republiek, 1572-1630. Sint-Niklaas: Danthe.

Bruijn, J. R. 1970. De Admiraliteit van Amsterdam in Rustige Jaren, 1713-1751. Amsterdam: Scheltema and Holkema.

Bruijn, J. R.; F. S. Gaastra; and I. Schoffer, eds. 1979-87. Dutch-Asiatic Shipping in the 17th and 18th centuries, 3 vols. 's-Gravenhage: Martinus Nijhoff.

Burke, Gerald. 1960. The Making of Dutch Towns. New York: Simmons-Boardman.

Burke, Peter. 1974. Venice and Amsterdam. A Study of Seventeenth-Century Elites. London: Temple Smith.

Bussemaker, T. 1907. "Lijst van Ambten en Officien ter Begeving Staande van Burgemeesteren van Amsterdam in 1749," in Bijdragen en Mededeelingen van het Historisch Genootschap, vol. 28, 474-518.

Butel, Paul. 1990. "France, the Antilles and Europe in the Seventeenth and Eighteenth Centuries: Renewals of Foreign Trade," in The Rise of Merchant Empires, J. Tracy, ed., 153-73. New York: Cambridge University Press.

Cau, Cornelis, ed. 1658. Groot Placaet-Boek, vol 1. s'Gravenhage.

Christensen, A. E. 1941. Dutch Trade to the Baltic about 1600. Studies in the South Toll Registers and Dutch Shipping Records. The Hague: Martinus Nijhoff.

Clark, G. N., and W. J. M. Eysinga. 1940. The Colonial Conferences between England and the Netherlands in 1613 and 1615, 2 vols. Leiden: E. J. Brill.

Colenbrander, H. T., and W. P. Coolhaas, eds. 1919-. Jan Pietersz. Coen. Bescheiden Omtrent Zijn Bedriff in Indie. s'-Gravenhage: Rijks Geschiedkundige Publicatien. 
De Jonge, J. C. 1861. Geschiedenis van het Nederlandsche Zeewezen, 4. Haarlem: A. C. Kruseman.

De Korte, J. P. 1984. De Jaarlijkse Financiele Verantwoording in de VOC. Leiden: Martinus Nijhoff.

Den Haan, Hans. 1977. Moedernegotie en Grote Vaart. Een Studie over de expansie van het Hollandse Handelskapitaal in de 16e en 17e Eeuw. Amsterdam: Socialistiese Uitgeverij.

De Vries, Jan. 1974. The Dutch Rural Economy in the Golden Age. New Haven: Yale University Press.

1976. The Economy of Europe in an Age of Crisis, 1600-1750. New York: Cambridge University Press.

De Vries, Johan. 1958. "De Ontduiking der Convooien en Licenten in de Republiek tijdens de 18e Eeuw." Tijdschift voor Geschiedenis, 71:3, 349-61.

Dillo, Ingrid. 1992. De Nadagen van de Verenigde Oostindische Compagnie, I7831795: Schepen en Zeevarenden. Amsterdam: De Bataafsche Leeuw.

Elias, Johan E. 1963 [1903-5]. De Vroedschap van Amsterdam, 2 vols. Amsterdam: Israel.

- 1923. Geschiedenis van het Amsterdamsche Regentpatriciaat. Den Haag: Martinus Nijhoff.

Elliot, J. H. 1986. "The Decline of Spain," in Crisis in Europe 1560-1600, 177-205. New York: Anchor Books.

Emmer, Pieter C. 1972. "The History of the Dutch Slave Trade, A Bibliographical Survey." The Journal of Economic History, 32:3 (September), 728-47.

- 1981. "The West India Company, 1621-1791: Dutch or Atlantic?," in Companies and Trade, Leonard Blusse and Femme Gaastra, eds., 71-95. Leiden: Leiden University Press.

Fockema Andreae, S. J. 1969. De Nederlandse Staat onder de Republiek. Amsterdam: Noord-Hollandsche Uitgevers Maatschappij.

Fritschy, J. M. F. 1988. De Patriotten en de Financien van de Bataafse Republiek. Hollands Krediet en de Smalle Marges voor een Nieuw Belied (1795-1801). Den Haag: De Bataafse Leeuw.

Furber, Holden. 1976. Rival Empires of Trade in the Orient, 1600-1800. Minneapolis: University of Minnesota Press.

Gaastra, Femme. 1982. De Geschiedenis van de VOC. Haarlem: Fibula-Van Dishoeck.

Giddens, Anthony. 1985. The Nation-State and Violence. Cambridge: Polity Press.

Glamann, Kristof. 1958. Dutch-Asiatic Trade 1620-1740. The Hague: Martinus Nijhoff.

Goslinga, Cornelis. 1971. The Dutch in the Caribbean and on the Wild Coast, 15801680. Assen: Van Gorcum.

. 1985. The Dutch in the Caribbean and in the Guianas, 1680-1791. Assen: Van Gorcum.

Gramsci, Antonio. 1971 . [1929-35]. Selections from the Prison Notebooks, Q. Hoare and G. N. Smith, eds. New York: International Publishers.

Hall, John. 1991. "The Patrimonial Dynamic in Colonial Brazil," in Brazil and the World System, Richard Graham, ed., 57-88. Austin: University of Texas Press.

't Hart, Marjolein. 1993. The Making of a Bourgeois State. War, Politics and Finance during the Dutch Revolt. New York: Manchester University Press.

. 1989. "Cities and Statemaking in the Dutch Republic, 1580-1680." Theory and Society, 18:5 (September), 663-87.

Heckscher, Eli. 1955 [1931]. Mercantilism, 2nd ed., 2 vols. New York: Macmillan. 
Hoboken, W. J. 1960. "The Dutch West-India Company: the Political Background of its Rise and Decline," in Britain and the Netherlands, vol. 1, J. S. Bromley and E. H. Kossmann, eds., 41-61. London: Chatto and Windus.

Hobsbawm, E. J. 1967. The Age of Revolution. 1789-1848. New York: Anchor Books.

Hopkins, Terence K., and Immanuel Wallerstein. 1982. World-Systems Analysis. Theory and Methodology. Beverly Hills, Calif.: Sage.

Howell, Martha. 1986. Women, Production, and Patriarchy in Late Medieval Cities. Chicago: University of Chicago Press.

Israel, Jonathan. 1992. "England's Mercantilist Response to Dutch World Trade Primacy, 1647-1674," in Britain and the Netherlands, vol. 10, 50-61, of State and Trade. Zutphen: Walburg Pers.

- 1989. Dutch Primacy in World Trade, 1585-1740. Oxford: Clarendon Press. 1982. The Dutch Republic and the Hispanic World 1606-1661. Oxford: Oxford University Press.

Jongkees, A. G. 1942. Staat en Kerk in Holland onder de Bourgondische Hertogen, 1425-1477. Amsterdam.

Klein, Peter Wolfgang. 1982. "Dutch Capitalism and the European World-Economy," in Dutch Capitalism and World Capitalism, Maurice Aymard, ed., 75-91. New York: Cambridge University Press.

Koenigsberger, H. G. 1982. "Why Did the States General of the Netherlands become Revolutionary in the Sixteenth Century?" Parliaments, Estates, and Representation, 2:1 (June), 103-111.

Kossmann, E. H. 1970. "The Low Countries," in The New Cambridge Modern History, vol. 4, J. P. Cooper, ed., 359-84. Cambridge: Cambridge University Press.

. 1978. The Low Countries, 1780-1940. Oxford: Clarendon Press.

Leidschrift. 1992. 1:9 (September).

Marvell, Andrew. 1972. The Complete Poems. New York: Penguin.

Marx, Karl. 1967 [1867-94]. Capital, 3 vols. New York: International Publishers.

Menkman, W. R. 1947. De Geschiedenis van de West-Indische Compagnie. Amsterdam: Van Kampen.

Merton, Robert. 1967. On Theoretical Sociology. Five Essays, Old and New. New York: Free Press.

Misra, Joya, and Terry Boswell. 1993. "Hegemony in the Capitalist World-Economy During the Age of Mercantilism." Unpublished manuscript.

Mokyr, Joel. 1975. "Capital, Labor, and the Delay of the Industrial Revolution in the Netherlands," in Economisch en Sociale-Historisch Jaarboek, vol. 38, 280300 .

Mosse, G. L. 1970. "Changes in Religious Thought," in The New Cambridge Modern History, vol. 4, J. P. Cooper, ed., 169-201. Cambridge: Cambridge University Press.

North, Douglass, and Robert Thomas. 1973. The Rise of the Western World. New York: Cambridge University Press.

Palmer, R. R. 1959-64. The Age of the Democratic Revolution, 2 vols. Princeton: Princeton University Press.

Parker, Geoffrey. 1977. The Dutch Revolt. London: Allen Lane.

. 1979. "Why Did the Dutch Revolt So Long?," in Spain and the Netherlands, 1559-1659. Ten Studies, 45-93. London: Collins.

Porta, Antonio. 1975. Joan en Gerrit Corver. De Politieke Macht van Amsterdam (1702-48). Assen: Van Gorcum. 
Posthumus, N. W. 1908-39. Geschiedenis van de Leidsche Lakenindustrie, 3 vols. 'sGravenhage: Martinus Nijhoff.

Postma, Johannes Menne. 1990. The Dutch in the Atlantic Slave Trade 1600-1815. Cambridge: Cambridge University Press.

Prak, M. 1985. Gezeten Burgers. De Elite in een Hollandse Stad: Leiden 1700-1780. Amsterdam: Dieren.

Prakash, Om. 1985. The Dutch East India Company and the Economy of Bengal, 1630-1720. Princeton: Princeton University Press.

Prestage, E. P. 1925. The Diplomatic Relations of Portugal with France, England and Holland from 1640 to 1668 . Watford: Ross and Michael Ltd.

Ramsay, G. D. 1986. The Queen's Merchants and the Revolt of the Netherlands: The End of the Antwerp Mart. Dover: Manchester University Press.

Raychaudhuri, T. 1962. Jan Company in Coromandel, 1605-1690. The Hague: Martinus Nijhoff.

Riley, J. C. 1980. International Government Finance and the Amsterdam Capital Market, 1740-1815. New York: Cambridge University Press.

Roorda, D. J. 1964. "The Ruling Classes in Holland in the Seventeenth Century," in Britain and the Netherlands, vol. 2, J. S. Bromley and E. H. Kossmann, eds., 10932. The Hague: Martinus Nijhoff.

Roorda, D. J., and H. van Dijk. 1971. "Sociale Mobiliteit onder Regenten van de Republiek," in Tijdschrift voor Geschiedenis, vol. 84, 306-28.

Rowen, Herbert H. 1988. The Princes of Orange. The Stadholders in the Dutch Republic. New York: Cambridge University Press.

Schama, Simon. 1977. Patriots and Liberators: Revolution in the Netherlands, 17801813. New York: Knopf.

. 1987. The Embarrassment of Riches. An Interpretation of Dutch Culture in the Golden Age. New York: Alfred A. Knopf.

Schneider, Jane. 1991. "Was There a Precapitalist World-System?," in Core/Periphery Relations in Precapitalist Worlds, Christopher Chase-Dunn and Thomas D. Hall, eds. Boulder: Westview Press.

Schoffer, I. 1988. "De Republiek der Verenigde Nederlanden, 1609-1702," in De Lage Landen van 1500 tot 1780 , I. Schoffer, H. van der Wee, and J. A. Bornewasser, eds., 167-267. Den Haag: Agon.

. 1964. "Naar Consolidatie en Behoud onder Hollands Leiding (1593-1717)," in 500 Jaren Staten-Generaal in de Nederlanden, S. J. Fockema Andreae and H. Hardenberg, eds. Assen: Van Gorcum.

Skocpol, Theda. 1977. "Wallerstein's World System: A Theoretical and Historical Critique." American Journal of Sociology, 82:5 (March), 1075-90.

Slicher van Bath, B. H. 1957. Een Samenleving onder Spanning. Geschiedenis van het Platteland in Overijssel. Assen: Van Gorcum.

Stern, Steve J. 1988. "Feudalism, Capitalism, and the World-System in the Perspective of Latin America and the Caribbean." The American Historical Review, 93:4, 829-72.

Steur, Jacob Johan. 1984. Herstel of Ondergang: de Voorstellen tot Redres van de Verenigde Oost-Indische Compagnie, 1740-1795. Utrecht: HES.

Stinchcombe, Arthur. 1968. Constructing Social Theories. Chicago: University of Chicago Press.

Swart, K. W. 1974 [1949]. The Sale of Offices in the Seventeenth Century. The Hague: Martinus Nijhoff.

Tilly, Charles. 1990. Coercion, Capital and European States, AD 990-1990. Cambridge: Blackwell. 
Tracy, James. 1985. A Financial Revolution in the Habsburg Netherlands, 1515-1565. Berkeley: University of California Press.

Van der Chijs, J. A. ed. 1885-88. Nederlandsch-Indisch Plakaatboek, vols. 1-5. Batavia/s'Gravenhage: Martinus Nijhoff.

Van Dam, Pieter. 1927-29. Beschryvinge van de Oostindische Compagnie, vols. 1-2, F. W. Stapel, ed. Den Haag: Martinus Nijhoff.

Van de Haar, Cornelis. 1961. De Diplomatieke Betrekkingen tussen de Republiek en Portugal, 1640-1661. Groningen: J. B. Wolters.

Van den Boogaart, E. 1982. "De Nederlandse expansie in het Atlantische gebied, 1590-1674," in Overzee: Nederlandse Koloniale geschiedenis 1590-1975, E. Van den Boogaart et al., eds., 112-144. Haarlem: Fibula-Van Dishoeck.

Van der Wee, H. 1978. "The Agricultural Development of the Low Countries as Revealed by the Tithe and Rent Statistics, 1250-1800," in Productivity of Land and Agricultural Innovation in the Low Countries, (1250-1800), H. van der Wee and E. van Cauwenberghe, eds., 1-23. Leuven: Leuven University Press.

- 1988. "De overgang van middeleeuwen naar Nieuwe Tijd," in De Lage Landen van 1500 tot 1780, I. Schoffer et al., eds., 11-37. Amsterdam: Agon.

Van der Woude, A. M. 1972. Het Noorderkwartier, 3 vols. Wageningen: Veenman. Van Deursen, A. T. 1964-65. "De Raad van State en de Generaliteit (1590-1606)," in Bijdragen der Geschiedenis van Nederland, vol. 19, 7-48.

Van Dillen, J. G. 1970. Van Rijkdom en Regenten. 's-Gravenhage: Martinus Nijhoff.

- 1974 [1970]. "Economic Fluctuations and Trade in the Netherlands," in Essays in European Economic History, P. Earle, ed., 199-211. Oxford: Clarendon Press.

- 1958. Het Oudste Aandeelhoudersregister van de Kamer Amsterdam. Den Haag: Martinus Nijhoff.

Van Eyck van Heslinga, E. S. 1988. Van Compagnie naar Koopvaardij. De Scheepvaartverbinding van de Bataafse Republiek met de Kolonien in Azie 1795-1806. Amsterdam: De Bataafse Leeuw.

Van Houtte, J. A. 1964. Economische en Sociale Geschiedenis van de Lage Landen. Antwerpen: De Haan.

Van Nierop, H. F. K. 1984. Van Ridders tot Regenten. De Hollandse Adel in de Zestiende en de Eerste Helft van de Zeventiende Eeuw. Amsterdam: De Bataafse Leeuw.

Van Rees, Otto. 1868. Geschiedenis der koloniale politiek van de republiek der Vereenigde Nederlanden. Utrecht: Kemink en Zoon.

Van Zanden, J. L. 1991. Arbeid tijdens het Handelskapitalisme. Opkomst en Neergang van de Hollandse Economie, 1350-1850. Bergen: Octavo.

Veenendaal, A. J. 1980. "De Republiek voor het laatst als Grote Mogendheid, 1702 1727," in (New) Algemene Geschiedenis van Nederlanden, vol. 9, 16-30. Haarlem: Fibula-Van Dishoeck.

Vlekke, B. M. 1945. Evolution of the Dutch Nation. New York: Roy.

Wallerstein, Immanuel. 1974. Capitalist Agriculture and the Origins of the European World-Economy in the Sixteenth Century, vol. 1 of The Modern World-System. New York: Academic Press.

1980. Mercantilism and the Consolidation of the European World-Economy, 1600-1750, vol. 2 of The Modern World-System. New York: Academic Press.

Watson, Ian Bruce. 1980. Foundation for Empire: English Private Trade in India, 1659-1760. New Delhi: Vikas. 
Weber. Max. 1968 [1992]. Economy and Society, 2 vols., G. Roth and C. Wittich, eds. Berkeley: University of California Press.

Vlekke, Bernard. 1945. Evolution of the Dutch Nation. New York: Roy Publishers. Westermann, J. C. 1948. "Statistische Gegevens over den Handel van Amsterdam in de Zeventiende Eeuw." Tijdschrift voor Geschiedenis, 61:1-2: 3-15.

Wilson, Charles. 1965. England's Apprenticeship, 1603-1763. London: Longman. 